Article

\title{
Corporate Environmental Disclosure in India: An Analysis of Multinational and Domestic Agrochemical Corporations
}

\author{
Anna Jessop ${ }^{1}$, Nicole Wilson ${ }^{1}$, Michal Bardecki ${ }^{2, *}$ and Cory Searcy ${ }^{3}$ \\ 1 Environmental Applied Science and Management, Ryerson University, Toronto, ON M5B 2K3, Canada \\ 2 Department of Geography and Environmental Studies, Ryerson University, Toronto, ON M5B 2K3, Canada \\ 3 Yeates School of Graduate Studies, Ryerson University, Toronto, ON M5B 2K3, Canada \\ * Correspondence: bardecki@ryerson.ca; Tel.: +1-(416)-979-5000 (ext. 6175)
}

Received: 11 August 2019; Accepted: 27 August 2019; Published: 5 September 2019

\begin{abstract}
The existing corporate environmental disclosure (CED) research focuses primarily on large companies operating in a single jurisdiction, leaving a gap of knowledge regarding the subsidiary operations of multinational corporations. In this study, consolidated narrative interrogation (CONI) is used to quantify CEDs presented in annual and stand-alone sustainability reports published over a 15-year span between 2002 and 2016 by agrochemical companies operating in India. Results show that the diversity, the quantity, and the quality of CED vary significantly, but generally each of them has been improving over time-most notably following the revisions to the Companies Act in 2013. The study finds that the subsidiaries of multinational agrochemical corporations implemented CED practices more strongly associated with those of domestic companies than those found in the reports produced by their parent companies. The CED of both subsidiary and domestic companies appears to reflect concerns of local legitimacy.
\end{abstract}

Keywords: corporate environmental disclosure; agrochemical industry; India; multinational corporations; subsidiaries; legitimacy theory

\section{Introduction}

Corporate environmental disclosure is generally thought of as "those disclosures that relate to the impact company activities have on the physical or natural environment in which they operate" [1] (p. 16). Formal corporate environmental disclosures (CEDs) available publicly have been produced by corporations at least since the 1980s [2]. There are several perceived benefits of environmental disclosure that impel corporations to publicly report. Corporations have the opportunity to improve their reputation, which in turn can improve competitive advantage, increase profit margins, attract investors, and increase the potential sales market [3]. These corporations can also benefit from cost-savings due to more efficient use of resources and reduced risk of legal actions or public slandering [3]. Social and economic factors such as increased profits and brand recognition have become significant considerations for corporations regarding voluntary disclosures [4-6]. Disclosure may also contribute to a corporation's strategic plan [6,7].

In the absence of legislation and regulation or interest from investors and stakeholders, a corporation may opt to not disclose environmental information, believing the costs of doing so outweigh the benefits [3,8-10]. Additionally, without legal requirements or regulation, disclosures may be inaccurate or may misrepresent information $[7,11]$.

The majority of CED research focuses on large companies, such as the Fortune 500 companies or the top listed corporations in a selected country [12-14]. There is a burgeoning literature concerning 
CED practice in developing economies. However, studies examining environmental disclosure of multinationals rarely include subsidiary corporations, and studies focused at a national level generally do not distinguish between domestic corporations and foreign-operated multinational subsidiaries. The studies have conflicting results. Some suggest that multinational companies based in a developed economy with subsidiaries in developing countries result in more substantial disclosure by the subsidiaries than is the case with domestic companies [15-19]. Other studies have found no impact or a negative impact of foreign ownership on subsidiaries' CED [20-24]. The voluntary nature of environmental disclosure may play a role in these inconsistencies [24].

Although countries differ in corporate social responsibility (CSR) practices [25,26], which can include CED, India has had a significant role in the expanding global commitment to CSR. The country has been one of the fastest growing and most dynamic major economies in the world $[27,28]$ and has been noted as a leader among emerging markets in adoption of CSR at a national scale [29]. India was a front-runner in introducing mandatory CSR. The literature examining aspects of CSR in India continues to grow-although that specifically directed at an understanding of the environmental character of the reporting remains limited.

This study focuses on the agrochemical industry in India. By looking at CED over a 15-year timespan, it assesses the evolution of reporting, particularly in light of regulatory changes in CSR that have occurred over time. The paper also provides insight into the extent to which multinational corporations implement comprehensive disclosure practices related to the environment throughout the entirety of their operations and if reporting practices among subsidiary companies are more strongly associated with the practice of parent companies or the country of operation.

Consolidated narrative interrogation (CONI) is used to quantify CEDs presented in annual and stand-alone sustainability reports published between 2002 and 2016. The agrochemical industry plays a prominent role in India and in India's economy, and the CEDs from these companies are of particular interest because of the environmentally sensitive nature of the industry.

\subsection{Background: The Agrochemical Industry}

The agrochemical industry has assumed an important role in continued global food security [30]. The industry is responsible for the production of pesticides, herbicides, fertilizers, phytohormones, and other growth aids [31,32]. Innovation in the agrochemical industry remains high as corporations continue to develop new products to meet increasingly stringent environmental standards and predict agricultural resistance to applied substances [31,32].

The Indian agrochemical industry began production in 1952 and grew to become among the largest producers of agrochemicals globally [33]. Producing products for both national use and export, India has become a preferred supplier of low-cost generic agrochemicals for non-patented compounds [34], involving both domestic producers and the subsidiaries of multinational corporations.

Generally, the industries that pollute more or that are environmentally sensitive companies tend to have higher levels of CED [35-37]. Concern over the agrochemical industry's role in environmental degradation and pollution has led to strict environmental standards for the production and the use of agricultural chemicals $[31,38]$. Many health and safety concerns continue to persist around the agrochemical industry, including impacts to wildlife, water contamination, and human health effects [33,38]. Most of the impacts on human health occur in high-risk populations in developing countries, including primary workers in production plants and residents in rural areas [33,39]. General populations may also be at risk [39]. In India, the Bhopal disaster in December 1984 at an agrochemical production facility was a key impetus for the regulatory framework for pollution control through the enactment of the Environment (Protection) Act 1986 [40]. Concerns over environmental and health issues related to the industry have been of concern and closely monitored by pollution control boards [41]. 


\subsection{Theoretical Framework}

Many theoretical frames have been applied to corporate disclosure [42,43]. Particularly prominent are stakeholder and legitimization theories. Stakeholder theory provides insights into the behaviour of subsidiaries of multinational corporations with regards to disclosure. Stakeholder theory holds that, while companies seek to respond to all stakeholders, vital corporate decisions are based on the values and the ethics of major stakeholders [44-46]. Top level managers of Indian companies have been shown to favour CSR approaches that reflect stakeholder interests [47,48]. If a corporation is utilizing a localized disclosure strategy, the influential stakeholders are local powers such as government, customers, and suppliers that vary based on country of operation. Legitimacy is acquired by meeting the societal expectations as expected by these groups. Whereas, if a corporation is adhering to a standardized disclosure strategy, the stakeholders in focus are primarily investors from the parent corporation, and legitimacy is acquired by meeting the expectations of those stakeholders in all countries of operation, which is inherently more heavily influenced by the societal expectation of a developed country.

Legitimacy and stakeholder theories are related; as Campbell et al. [49] (p. 559) suggest, legitimacy theory may be regarded as "a subsidiary theory of the stakeholder metanarrative in that a number of constituencies are recognized" that "takes a more descriptive view of how a company addresses and deals with those constituencies". Legitimacy theory is widely used largely because corporate disclosures are the main means by which a corporation can demonstrate that they are fulfilling the expectations of society [50]. Legitimacy theory expects that organizations act in a way that abides by societal norms and expectations $[51,52]$ and maintain their legitimacy or reputation by meeting the expectation of society as a whole, thereby increasing organizational survival [53-55]. In order to obtain and maintain their legitimacy, corporations may also disclose information that does not accurately depict the corporations' environmental performance $[8,52,54]$. This is not always done in an attempt to greenwash corporate activities. Although this certainly occurs, it can also be an attempt to secure corporate legitimacy by not drawing attention to areas of operation that may not fulfill society's expectations [11]. As a result, the relationship between environmental reporting and environmental performance is not always strong [2,52,56].

Multinational corporations face greater complexity in achieving and maintaining legitimacy [57]. This is because, in addition to facing the complex institutional environment that all organizations encounter, multinationals also face increased complexity within the corporation itself caused by fragmentation, operation in several institutional environments, and "liability of foreignness" (i.e., the obstacles faced by corporations operating in a foreign market) [57,58]. Archel et al. [59] emphasize that legitimacy strategies are linked to the political environment within which a company operates; these include "the patterns of corporate ownership, business law and regulation, state intervention in commercial activities, the influence of religious or ethnic considerations, the degree of public concern about the environment, the prominence of civil society and attitudes to philanthropy or social responsibility" [60] (pp. 545-546). A subsidiary company of a business operating in different countries is potentially subject to both decisions of the parent company as well as to the context of the parent company's places of operation [61]. Subsidiaries may respond more to their own need to seek legitimacy within the context of local norms and expectations.

Related to the ideas of legitimacy and stakeholder theory are those underpinning institutional theory. DiMaggio and Powell [62] contend that firms come to exhibit similar values, structures, and practices as a result of isomorphic pressures from three sources: (1) coercive (that is, legal and regulatory); (2) mimetic (stakeholders); and (3) normative (professional community-related). Those stakeholders who have the greatest power over the firm are able to better demand the information they require or desire. Being that countries have differing legal, socio-political, and cultural contexts, institutional theory suggests that companies operating in different national contexts behave differently. In fact, in reference to multinational corporations, Kostova and Roth [63] argue that companies are subject to an "institutional duality" whereby they are exposed to institutional pressures from both 
host and home countries. A number of studies provide evidence for this phenomenon [63-67]. Being that multinational corporations operate in a variety of national contexts, this creates tension because they must decide whether to adapt practices to local conditions or gain potential advantages by standardizing their global operations [68]. Furthermore, there can be challenges in establishing proper oversight mechanisms [69].

\subsection{Corporate Environmental Disclosure in India}

In some Indian companies, elements of environmental disclosure have been incorporated traditionally as part of their financial disclosure [70,71]. Kumar et al. [72] trace the development of CSR through four stages, corresponding to pre-independence, the statist mixed-plan economy, the period of liberalization and globalization, and the recent move to a stakeholder participation approach. The tenets of religious faith in India are seen as having played a historic and continuing role in the history of a commitment to CSR activity [73-76]. In India and other developing countries, CSR may be driven by more philanthropic motives than would be the case for companies in developing countries [77,78].

The Government of India made its first public statement concerning the need for environmental disclosure in companies' annual reports in 1991 [79]. However, until 2011, all environmental disclosures from corporations operating in India were voluntary for all companies, with the exception of submitting a statement to the Pollution Control Board [80]. In 2011, the Ministry of Corporate Affairs published a set of "National Voluntary Guidelines on Social, Environmental, and Economic Responsibilities of Business." These guidelines provided the principles and the format for responsibility disclosures by businesses [81]; they were made mandatory for the largest 100 companies (based on market capitalization at the Bombay and National Stock Exchanges). This brought increased pressure on other companies to follow suit. As part of continuing changes in corporate governance reform [82,83], from 2015 onward, the Indian government, through revisions to the Companies Act in 2013, made it mandatory for corporations with annual revenues in excess of 10 billion rupees to publish information regarding their CSR policy and to commit $2 \%$ of their average net profit on CSR activities $[84,85]$. The Act requires publication of details regarding a CSR committee and its responsibilities, a CSR board statement, and a CSR policy-failure to do is punishable by fines [86]. However, corporations can fulfill the requirements of the Act without incorporating environment disclosures, instead focusing on health, education, and charity initiatives [86]. Even under the umbrella of "sustainability reporting", the focus has been far more on social and cultural issues rather than environmental issues $[87,88]$.

Companies operating in India have incorporated CED; however, the disclosure has been widely criticized [23], in part due to the tendency of corporations to report exclusively on positive environmental aspects while dismissing negative impacts [19]. No external auditing process has been established to monitor companies' CSR actions and reporting. Singh et al. [89] identify a need for further legislative change requiring more prescriptive policies, particularly in monitoring and evaluation. Overall, there is concern that the Act may reduce the value of CSR initiatives, as the Act fails to specify requirements regarding quantity or quality [86] and may have other adverse impacts on businesses [90,91]. Others have suggested that mandatory regulation increases the quality and the quantity of environmental disclosure from corporations as a result of the expectation that corporations first and foremost strive to meet legal requirements, and failure to do this would significantly impact the corporations' reputation and legitimacy $[92,93]$.

CED is one aspect of companies' reporting of their CSR activities. A number of studies have been undertaken investigating the reporting of CED in India. Table 1 documents studies that have investigated CED reporting among Indian companies. Although the research on CED overlaps with that of CSR disclosure more generally, which includes consideration of environmental concerns (e.g., [94-96]), these studies are not included here. 
Table 1. Studies investigating corporate environmental disclosure (CED) in India.

\begin{tabular}{|c|c|c|c|c|c|c|c|c|}
\hline & Sample Frame & $\begin{array}{c}\text { Foreign } \\
\text { Ownership }\end{array}$ & $\begin{array}{l}\text { Number of } \\
\text { Firms }\end{array}$ & $\begin{array}{c}\text { Theoretical } \\
\text { Underpinning }\end{array}$ & $\begin{array}{c}\text { Number of } \\
\text { Years }\end{array}$ & Basis of Analysis & $\begin{array}{l}\text { Number of Environmental } \\
\text { Components }\end{array}$ & $\begin{array}{l}\text { Focus of } \\
\text { Analysis }\end{array}$ \\
\hline $\begin{array}{c}\text { Chatterjee \& Mir } \\
\text { (2008) [97] }\end{array}$ & Largest Indian companies & No & 23 & $\begin{array}{c}\text { Legitimacy } \\
\text { Organizational }\end{array}$ & 1 & $\begin{array}{l}\text { Characterization of the } \\
\text { nature of the information }\end{array}$ & - & $\begin{array}{c}\text { Annual Reports } \\
\text { \& Websites }\end{array}$ \\
\hline Pahuja (2009) [36] & $\begin{array}{c}\text { Large Indian } \\
\text { manufacturing } \\
\text { companies }\end{array}$ & Yes & 91 & Empirical & 3 & Index based on 23 items & 23 & Annual Reports \\
\hline $\begin{array}{l}\text { Mukherjee et al. } \\
\quad \text { (2010) [98] }\end{array}$ & $\begin{array}{l}\text { Indian companies in } 10 \\
\text { sectors }\end{array}$ & No & 80 & $\begin{array}{l}\text { Agency, } \\
\text { Legitimacy, } \\
\text { Stakeholder }\end{array}$ & 1 & $\begin{array}{c}\text { Scoring of } 20 \text { themes, } \\
\text { based on a ternary rating }\end{array}$ & 20 & Annual Reports \\
\hline Joshi et al. (2011) [37] & $\begin{array}{l}\text { Indian industrial } \\
\text { companies }\end{array}$ & No & 45 & Legitimacy & 1 & $\begin{array}{l}\text { Scoring of } 19 \text { items, based } \\
\text { on a ternary rating }\end{array}$ & 19 & Websites \\
\hline Sen et al. (2011) [80] & $\begin{array}{l}\text { "Core sector companies" } \\
\text { in } 4 \text { major industries }\end{array}$ & Yes & 22 & Empirical & 1 & $\begin{array}{c}\text { Prevalence of occurrence } \\
\text { of } 15 \text { themes }\end{array}$ & 15 & Annual Reports \\
\hline $\begin{array}{l}\text { Bhasin et al. (2014) } \\
\text { [99] }\end{array}$ & Large Indian companies & No & 30 & Empirical & 1 & $\begin{array}{l}\text { Scoring of } 12 \text { items, based } \\
\text { on a quaternary rating }\end{array}$ & 12 & Annual Reports \\
\hline $\begin{array}{c}\text { Debnath et al. (2014) } \\
\text { [100] }\end{array}$ & $\begin{array}{l}\text { Indian companies } \\
\text { participating in GRI } \\
\text { reporting process }\end{array}$ & No & 16 & Empirical & 3 & $\begin{array}{l}\text { GRI reporting by } \\
\text { companies }\end{array}$ & 17 required; 13 optional & GRI Reports \\
\hline Goyal (2014) [101] & $\begin{array}{l}\text { Large Indian companies } \\
\text { in } 5 \text { sectors }\end{array}$ & No & 50 & Stakeholder & 1 & $\begin{array}{c}\text { Dichotomous scoring of } \\
35 \text { items }\end{array}$ & 35 & Annual Reports \\
\hline $\begin{array}{c}\text { Maheshwari \& Kaura } \\
\text { (2014) [102] }\end{array}$ & $\begin{array}{l}\text { Random companies in } \\
\text { the BSE } 100 \text { Index }\end{array}$ & No & 30 & Empirical & 2 & $\begin{array}{l}\text { Scoring of } 6 \text { items, based } \\
\text { on a ternary rating }\end{array}$ & 6 & Annual Reports \\
\hline $\begin{array}{l}\text { Chaklader \& Gulati } \\
\text { (2015) [23] }\end{array}$ & Large Indian companies & No & 50 & $\begin{array}{l}\text { Legitimacy, } \\
\text { Agency }\end{array}$ & 4 & $\begin{array}{c}\text { "Environmental } \\
\text { Disclosure Index" } \\
\text { (dichotomous scoring) }\end{array}$ & Not specified & Annual Reports \\
\hline $\begin{array}{c}\text { Kumar et al. (2015) } \\
\text { [103] }\end{array}$ & $\begin{array}{l}\text { Indian companies in } 10 \\
\text { sectors }\end{array}$ & No & 36 & Stakeholder & 1 & $\begin{array}{l}\text { Words counts of terms } \\
\text { related to } 3 \text { dimensions of } \\
\text { sustainability }\end{array}$ & 1 & CSR Reports \\
\hline $\begin{array}{l}\text { Barman \& Gautam } \\
\quad(2016)[104]\end{array}$ & Large Indian companies & No & 12 & Empirical & 1 & $\begin{array}{l}\text { Dichotomous scoring of } \\
33 \text { items }\end{array}$ & 33 & Annual Reports \\
\hline $\begin{array}{l}\text { Ezhilarasi \& Kabra } \\
\quad \text { (2016) [105] }\end{array}$ & $\begin{array}{l}\text { Companies in most } \\
\text { polluting industries in } \\
\text { India }\end{array}$ & Yes & 53 & Empirical & 5 & $\begin{array}{l}\text { Dichotomous scoring of } \\
46 \text { items }\end{array}$ & 46 & Annual Reports \\
\hline $\begin{array}{l}\text { Malarvizhi \& Matta } \\
\text { (2016) [106] }\end{array}$ & $\begin{array}{l}\text { Indian energy, chemical } \\
\text { and metal industries }\end{array}$ & No & 85 & Empirical & 1 & $\begin{array}{l}\text { Scoring of } 19 \text { items, based } \\
\text { on a quaternary rating }\end{array}$ & 19 & $\begin{array}{c}\text { Annual, } \\
\text { Sustainability \& } \\
\text { GRI Reports }\end{array}$ \\
\hline $\begin{array}{c}\text { Omnamasivaya \& } \\
\text { Prasad (2016a) [107] }\end{array}$ & $\begin{array}{l}\text { National Stock Exchange } \\
\text { of Indian's NIFTY } 50\end{array}$ & Yes & 50 & Legitimacy & 1 & $\begin{array}{c}\text { Dichotomous scoring of } \\
20 \text { items }\end{array}$ & 20 & Annual Reports \\
\hline
\end{tabular}


Table 1. Cont

\begin{tabular}{|c|c|c|c|c|c|c|c|c|}
\hline & Sample Frame & $\begin{array}{c}\text { Foreign } \\
\text { Ownership }\end{array}$ & $\begin{array}{l}\text { Number of } \\
\text { Firms }\end{array}$ & $\begin{array}{c}\text { Theoretical } \\
\text { Underpinning }\end{array}$ & $\begin{array}{c}\text { Number of } \\
\text { Years }\end{array}$ & Basis of Analysis & $\begin{array}{l}\text { Number of Environmental } \\
\text { Components }\end{array}$ & $\begin{array}{l}\text { Focus of } \\
\text { Analysis }\end{array}$ \\
\hline $\begin{array}{c}\text { Omnamasivaya \& } \\
\text { Prasad }(2016 b, 2017) \\
{[108,109]}\end{array}$ & BSE 30 companies & No & 30 & Empirical & 5 & $\begin{array}{l}\text { Dichotomous scoring of } \\
28 \text { items }\end{array}$ & 28 & Annual Reports \\
\hline $\begin{array}{l}\text { Chandok \& Singh } \\
\text { (2017) [110] }\end{array}$ & Large Indian companies & No & 100 & Legitimacy & 1 & $\begin{array}{c}\text { Scoring of } 33 \text { items, based } \\
\text { on a ternary rating }\end{array}$ & 33 & $\begin{array}{c}\text { Websites \& } \\
\text { Annual Reports }\end{array}$ \\
\hline $\begin{array}{l}\text { Prasad et al. (2017) } \\
\text { [111] }\end{array}$ & Large Indian companies & Yes & $\begin{array}{l}137(134 \text { in } \\
2014-2015\end{array}$ & Legitimacy & $\begin{array}{l}2 \text { (2011-2012, } \\
\text { 2014-2015 }\end{array}$ & $\begin{array}{l}\text { Scoring of } 39 \text { items, based } \\
\text { on a ternary rating }\end{array}$ & 39 & Annual Reports \\
\hline
\end{tabular}


The CED studies differ substantially in the focus of the research and in their approaches and methods. Unlike some of the studies of the broader CSR research that investigated a specific industrial sector (e.g., [112-114]), they each investigated companies across multiple sectors. Half of the studies were empirical in nature (i.e., theories may be mentioned but do not form the basis of either method or discussion). In others, the research was framed through the lenses of one or more of legitimacy, stakeholder, agency, and organizational theories; as suggested above, legitimacy and stakeholder theories are the most common.

The majority (11 of 18$)$ of studies were cross-sectional in design (i.e., incorporating an analysis for a single year). Although some studies investigated change over time, particularly focusing on the potential impact of regulatory change by examining CSR reporting prior to and after the revisions to the Companies Act 2013, they do not take a longitudinal perspective- - the longest time span considered being five years.

Papers differ significantly in the number of companies included in the analysis (from 12 to 137). The differences generally reflect the intricacy involved in the method employed. The majority of the papers use companies' annual reports (or sections therein) as the source of data. In some studies, websites were used as alternative or additional sources. Five of the studies examined CSR reports, alone or in conjunction with other information found on companies' websites. Reports by or for an external non-government organization (NGO) were used in one study [106], and that was the only one that explicitly included analysis of information from standalone sustainability reports as well as annual reports.

Four papers gave some consideration to whether domestic firms and those that are subsidiaries of foreign companies differ in their CSR reporting. There is a sense in the broader literature that a number of elements associated with globalization ("internationalization") may impact the uptake of CSR by corporations. There are indications that companies that are more international (e.g., with more income from exports, exposure on foreign stock markets, or more shares held by foreign interests) tend to have higher levels of CSR disclosure (e.g., [115-118]). The premise is, in part, based on the proposition that, in the absence of domestic pressure, companies are more influenced by foreign stakeholders [14]. However, studies in disparate countries have not been able to consistently identify the effect of foreign ownership on CSR [21,22,43,119]. Momin and Parker [43] discovered that multinational subsidiaries in Bangladesh in several industries had very low levels of CSR reporting, which they attributed to the lack of mandatory requirements and pressure to conform (i.e., a lack of local legitimacy pressure).

Those studies specifically related to the impact of "internationalization" on the CSR disclosures of companies in India present an uneven array of conclusions. Ezhilarasi and Kabra [120] found that "foreign institutional ownership is the most important corporate governance attribute that engages corporates in environmental disclosure behavior" (p. 48). Additionally, Cordeiro et al. [76] suggested that multinational corporations seek legitimacy and may exhibit strong commitment to engaging in CSR directed locally-even exceeding the local norms. Yet, Chandok and Singh [110] identified "involvement in foreign business" to be significantly, although negatively, correlated with environmental disclosure on companies' websites (although incongruously, not for environmental disclosure in Annual Reports). Tewari [94] found that Indian companies outperformed multinational corporations in the aspects of CSR related to the environment. Two studies from the same research group found contradictory results concerning the possibility of international brand-name companies imposing their values regarding social and environmental disclosure on suppliers in order to maintain control of their image [95,121]. Omnamasivaya and Prasad [107] hypothesized that subsidiaries would report more than domestic firms yet found the relationship to be negative (albeit not significantly). Narwal and Singh [122] found little difference between domestic and subsidiary companies in terms of CSR disclosure, indicating that multinationals tended to follow the practice in the host country. Pahuja [36] did not identify any significant influence of foreign ownership on CED in the annual reports of large manufacturing companies. Moreover, Prasad et al. [111] investigated the relationship 
of ownership by foreign investors on CED by Indian companies listed on the Bombay Stock Exchange and did not find a significant association - a result similar to that of Sen et al. [80].

\subsection{Hypothesis Development}

A wide range of literature on CED exists; however, there has been little focus on how the CEDs of subsidiary operations align with those of their parent corporations $[12,13,123]$. The purpose of this research is to examine the extent to which the environmental reporting practices of parent multinational corporations (P-MNCs), their subsidiaries operating in India (I-MNCs), and domestic Indian companies in the same industry (i.e., agrochemicals) resemble one another, with particular focus given to the extent of standardization within multinational corporations. These practices are examined over a span of 15 years (2002-2016). Based on a reading of the literature, two specific hypotheses are developed.

The history of CED research has witnessed an ever-increasing pattern of environmental disclosures for many corporations, primarily large corporations in developed countries [120]. Past research has shown the detail of the coverage with CEDs has generally increased over time [124]. Consequently, the first hypothesis posits that all companies will increase the diversity, the quantity, and the quality of their environmental disclosures over the timeframe examined.

Studies in India often assert, without references, that there has been an increase in CSR disclosure over some undisclosed period of time. The sense is that there have been positive changes in reporting practices over time in India [125-127]. Some studies assert a change in CSR disclosure based on the evidence of two years.

Hypothesis 1 (H1). The corporations studied will increase the diversity, the quantity, and the quality of environmental disclosures over the whole time period examined.

The influence of regulatory and other legal pressures on CED have been recognized in a variety of jurisdictions (e.g., [128-130]). Of particular interest in India has been the effect that the revisions to the Companies Act in 2013 have had on CED through the introduction of mandatory requirements for CSR. There have been relatively few other jurisdictions that have instituted mandatory CSR requirements, Indonesia [131] and South Africa [132] being two of them. Some research has contributed to a critique of mandatory enforcement of CED [91,133-135]; in contrast, others have reported positively in terms of CED practice and overall company performance associated with reforms leading to requirements for mandatory CED $[93,96]$.

Initially, in India, the proposed changes to mandatory CED were generally positively received in the financial markets (Bird et al. 2016). However, an initial intense debate developed [91,136,137]. In the period following enactment of the Companies Act 2013, compliance started slowly among those companies required to spend $2 \%$ (of their average net profit) on CSR activities [85,138]; indeed, companies that had been involved in CED may have reduced their spending [91]. Mukherjee et al. [91] suggest that the Companies Act 2013 changes have failed to meet expectations, in part since they have negatively affected company profitability. Results from Manchiraju and Rajgopal [139] indicate that mandatory CSR may have increased burdens on companies and suggest that the stock price for companies required to spend monies to meet the requirements of the Companies Act 2013 experienced declined.

On the other hand, KPMG in its 2018 CSR Reporting Survey reports that compliance is now "near universal" [140] (p. 1), and generally positive outcomes with regard to CSR compliance have been found [141,142].

Bergman et al. [143] undertook a broad analysis of the literature published both prior to and after the enactment of the Companies Act in 2013. They found that advantages and disadvantages were identified both in terms of the conceptual foundation of the Act and in practice. These form the basis for disagreement among academics, as what is identified on one side as an advantage is seen by others as a disadvantage. They conclude that "the resulting tension is indicative of the complexity of CSR and 
the manifold challenges associated with appropriately defining and operationalizing responsibilities for the business sector. It also lays bare the difficulty of successfully connecting CSR to the context and culture within which business are embedded" [143] (p. 13). They bemoan the lack of empirical evidence in the literature.

Some studies have been undertaken to investigate changes in CSR disclosure from the period immediately before the change came into effect to the period after. Bhatia and Dhawan [144] noted an increase in the overall CSR disclosure by large Indian companies when comparing 2013-2014 to 2015-2016, but this was not the case for two of the three environmental items included in their analysis. Among 137 companies listed in the Bombay Stock Exchange, Prasad et al. [111] did note an increase in environmental disclosure from 2011-2012 to 2014-2015, but it was not statistically significant. A third paper by Ghosh [145] noted an increase in reporting on CSR activities between 2011-2012 and 2013-2014 (i.e., after the announcement of the changes but prior to full implementation).

Goel [96] observed that, generally, little attention has been paid by researchers to the manifest effects of the Companies Act reforms on reporting. In reference to the Companies Act 2013, Prasad et al. [111] did speculate that "mandatory reporting may increase the extent of information disclosed (the items on which information is disclosed), yet the quality of these disclosures may remain largely descriptive and lack quantitative details, as the criteria for the disclosures have not been clearly specified in the regulations" (p. 2018).

Hypothesis 1a (H1a). In the period spanning the introduction and the implementation of the Companies Act 2013, the corporations studied will increase the diversity and the quantity of environmental disclosures over the time period examined; however, change in the quality of disclosures will lag.

There is extensive literature that examines the impact that company-specific factors and other general contextual factors have on CED practices $[60,146,147]$. Among the key factors identified are company size, the nature of corporate governance, and a variety of companies' financial attributes. Company size has been identified as having a positive relationship with the CED practices $[7,148,149]$ with large, highly visible companies tending to have a higher quantity and quality of CEDs than small, less visible companies. Another potentially important driver that has been identified is the nature of corporate structure and governance $[17,105,150]$. Generally, the results of studies investigating the relationship between a variety of financial factors (e.g., profit, leverage, stock exchange membership) have been mixed $[21,26,127,151]$. For example, although some studies indicate that there is only a weak association between a company's profitability and CED [61,152,153], others have found a positive association $[154,155]$.

The issue of investigating the nature of CED by subsidiary companies has been part of a number of studies in a variety of countries (e.g., Bangladesh [43], Canada [7], Spain [61,156], Malaysia [157]). However, although more general reviews of CSR exist, no comprehensive international review has yet been undertaken to examine the nature of the relationship between CED and subsidiary companies. There generally has been more attention given to the issue in India than elsewhere, which allows this study to fit into existing literature. Corporations in developing countries tend to have lower levels of CED [158]. Research suggests that there are differences between environmental disclosures produced by corporations operating in developed and developing countries, with these differences attributed to the resources available, public scrutiny, and business culture $[14,159,160]$. Many of these factors depend on the ownership scheme of a corporation; foreign ownership is believed to have an impact on the level of disclosure from corporations operating in developing economies, although conflicting results fail to conclude if this is positive or negative [20-24]. The question if multinational corporations standardize CEDs in all areas of operation, including their operations in developed and developing countries of operation, is of interest $[8,50,161]$. Some research has shown that, across several countries and industries, foreign ownership has little or negative impact on environmental disclosure [23,24,162], as international corporations operating in developing countries disclosed in a way that was similar 
to (or even poorer than) domestic corporations. However, there are studies indicating that foreign ownership has a positive effect on environmental disclosure [117,163]. The studies in India that sought to discern a difference between domestic and subsidiary companies in nature of their environmental disclosure (Table 1) do not, as a group, provide clear evidence of a difference. The second hypothesis follows from these observations.

Hypothesis 2 (H2). The diversity, the quantity, and the quality of environmental disclosures of I-MNCs will be more similar to those of domestic corporations than those of the parent corporation.

The hypotheses were first tested using content analysis to characterize the data and then analyzed using simple linear regression and two-way repeated measures ANOVA.

\section{Methods}

\subsection{Sample Selection}

Three categories of corporations were identified: parent multinational corporations (P-MNCs), Indian-based subsidiaries of the multinational corporation (I-MNCs), and domestic Indian corporations. Multinational parent corporations refer to the headquarters operations of a multinational agrochemical corporation, while the multinational subsidiary companies are subsidiary companies of the same multinational corporation located in India. Domestic corporations are national, publicly traded corporations operating in India in the agrochemical industry.

Selection of the multinational corporations was determined by first compiling a list of agrochemical corporations using the online database Datamonitor [164]. From these, corporations with their primary business operations in agrochemicals that were based in North America or Europe and that had a subsidiary corporation operating in India were selected. Among the 19 corporations meeting the selection criteria, four were randomly selected and included in the study: Bayer CropScience AG, Syngenta AG, BASF SE, and Monsanto Company. The Indian subsidiary corporations were selected corresponding to the parent multinational corporations; these corporations operate under the names Bayer CropScience (India), Syngenta India Ltd., BASF India Ltd., and Monsanto India Ltd., respectively. Domestic Indian corporations were selected by compiling a list of Indian agrochemical companies. From those of comparable size to the subsidiary companies, four leading companies that were publicly traded and had their primary business operations in agrochemicals were randomly selected. These corporations were United Phosphorus Ltd. (UPL), Zuari Agro Chemical Ltd., Rallis India Ltd., and Coromandel International Ltd. For each of the 12 companies included in the study, data were collected from publicly available annual reports and stand-alone environmental or sustainability reports, which had been released over a 15-year period (2002-2016).

Given the regulatory requirement for their production by companies, annual reports are generally seen as reliable, consistent, and inclusive sources and are by far the most frequent source for studies of CSR content. Information provided on a voluntary basis, such as in environmental and sustainability reports, can be more informative of a company's actual environmental commitment [165]. Standalone reports can signal a commitment to CSR; focusing research on the mandatory annual reports alone may lead to misleading conclusions [166]. However, generally, CED reports remain uncommon in India [110]. Nonetheless, given that large companies in India are more likely to release sustainability reports [145] and with the legitimacy pressures on the agrochemical industry, except for one company's reports in three years, the necessary reports were available for this study.

\subsection{Content Analysis}

This study utilizes content analysis to quantify the qualitative and the quantitative information published by the selected corporations. Content analysis is a common tool used to systematically analyze reports and written material $[167,168]$. The most common method used in the CSR literature 
is the creation of a composite disclosure index from the document(s). These indices can incorporate a large number of attributes, but no approach has been generally accepted (Table 1). The content analysis approach used in this study was Consolidated Narrative Interrogation (CONI). Developed by Beck et al. [168], it is specifically tailored for the analysis of environmental information.

CONI provides the means to create a hybrid of mechanistic and interpretive approaches to develop content analysis that is comprehensive [168]. Most CED studies in India have determined a single metric for the extent of disclosure (e.g., an index based on the presence or the absence, or some simple weighting, of a series of items that might be expected to be included in a document). Any consideration of quality is subsumed in the single value of the index (i.e., through the weighting). Prasad et al. [111] expanded their analysis to retain a second dimension (i.e., of quality). CONI provides a more comprehensive analysis of the data by allowing the user to rate a unit of a document simultaneously on three criteria - the quantity, the diversity, and the quality of the text-by recording the overall amount of relevant information, the character of the disclosure, and the quality of the information. The unit for measurement is the sentence rather than the documents as a whole.

This research analyzed data collected by two coders. To ensure the reliability of the data, a coding manual was created, and inter- and intra-rater reliability testing was performed on a $10 \%$ sample of documents. Intra-rater reliability was calculated as 0.91 and inter-rater reliability as 0.85 using Krippendorf's alpha. Krippendorf's alpha is considered conservative, and a score above 0.80 is widely viewed as acceptable [169].

The quantity of environmental disclosures is measured by identifying the total number of sentences containing environmentally-relevant information in a document.

Diversity in each sentence is assessed by identifying the presence of environmentally-relevant thematic categories and sub-categories [168]. The more categories included, the more diverse the text. For this study, the categories from Beck et al. [168] were expanded to include 18 categories and 59 sub-categories (Table 2). The additional categories were developed to better suit the application of the method specifically to the disclosures of agrochemical companies and to address emerging environmental issues. The categories added were tested to ensure that they were reliable and mutually exclusive. In addition, two of Beck et al.'s categories were removed since they were subsumed into the new categories.

Table 2. Diversity coding categories and sub-categories for Consolidated Narrative Interrogation (CONI) diversity analysis.

\begin{tabular}{ll}
\hline \multicolumn{1}{c}{ Category } & \multicolumn{1}{c}{ Sub-Category } \\
\hline & 1: Any general mention \\
& 2: Aims, goals or commitments \\
& 3: Management systems and processes \\
GEN: General environmental & 4: Disclosure guidelines, including GRI \\
5: Environmental initiatives, i.e., REACH & 6: Results from audits, policies, etc. \\
& 7: Long-term policy, goals, etc. \\
& 8: Continuous improvement * \\
& 9: Top management/department \\
& 10: Management individual/membership \\
& 11: Management aims and objectives \\
RES: Those responsible for the & 12: Results \\
environmental behaviour or & 13: Reference to employees \\
implementation of activities &
\end{tabular}


Table 2. Cont.

\begin{tabular}{|c|c|}
\hline Category & Sub-Category \\
\hline POLL: Pollution & $\begin{array}{l}\text { 14: Air emissions (actual and result) } \\
\text { 15: Air action/target } \\
\text { 16: Water emissions (actual and result) } \\
\text { 17: Water action/target } \\
\text { 18: Waste emitted (actual and result) } \\
\text { 19: Waste action/target } \\
\text { 20: Recycling (must include the word recycle) } \\
\text { 21: Land emission (actual and result) } \\
\text { 22: Land action/target } \\
\text { 23: Emission and pollution related to products }\end{array}$ \\
\hline PROD: Product disclosures & $\begin{array}{l}\text { 24: Product stewardship * } \\
\text { 25: Mention of environmentally friendly products * }\end{array}$ \\
\hline SUST: Sustainability disclosure & $\begin{array}{l}\text { 26: General mention of sustainability } \\
\text { 27: Commitment to UNCED, Kyoto, etc. } \\
\text { 28: Biodiversity conservation } \\
\text { 29: Mention of climate change* }\end{array}$ \\
\hline ACT: Environmental Activities & $\begin{array}{l}\text { 30: Staff training } \\
\text { 31: Project involvement (without partnership) } \\
\text { 32: Awards } \\
\text { 33: Sponsoring } \\
\text { 34: Partnerships (must use word partner/partnership) * }\end{array}$ \\
\hline BRR: Business Risk & $\begin{array}{l}\text { 35: Environmental risks related to business } \\
\text { 36: Attempts to manage or reduce environmental risks } \\
\text { 37: Related costs }\end{array}$ \\
\hline PRESS: Pressure Groups & $\begin{array}{l}\text { 38: Shareholders } \\
\text { 39: Stakeholders } \\
\text { 40: Government }\end{array}$ \\
\hline $\begin{array}{l}\text { SER: Separate Environmental } \\
\text { Report }\end{array}$ & $\begin{array}{l}\text { 41: Separate report references } \\
\text { 42: Contact details }\end{array}$ \\
\hline RC: Responsible Care & 43: Any mention of Responsible Care * \\
\hline ENE: Energy Disclosure & $\begin{array}{l}\text { 44: Conservation/ energy saving attempts (goals and results) } \\
\text { 45: Energy use, development, and exploration of alternative energy } \\
\text { 46: Energy usage* }\end{array}$ \\
\hline INP: Resource Input & $\begin{array}{l}\text { 47: Water Input* } \\
\text { 48: Resource Input, renewable, non-renewable, toxic, etc. * }\end{array}$ \\
\hline SUPP: Supplier Related Disclosure & $\begin{array}{l}\text { 49: Mention of sustainable supply chain, environmental requirements, } \\
\text { and/or supplier compliance * }\end{array}$ \\
\hline COMP: Compliance Disclosure & $\begin{array}{l}\text { 50: Compliance with environmental laws, regulations, and/or voluntary } \\
\text { compliance with initiatives * } \\
\text { 51: Non-compliance, including fines and lawsuits * }\end{array}$ \\
\hline IRP: Information Retrieval Process & 52: The process to obtain feedback from stakeholders * \\
\hline OTHER & $\begin{array}{l}\text { 53: Disclosure not fitting in the above categories, i.e., transportation, } \\
\text { transparency, accountability, etc. }\end{array}$ \\
\hline $\begin{array}{l}\text { ECE: External Environmental } \\
\text { Factors }\end{array}$ & $\begin{array}{l}\text { 54: Mention of weather-related information, including droughts and } \\
\text { rainfall, but excluding related business risks* }\end{array}$ \\
\hline
\end{tabular}

* The 14 sub-categories not included in Beck et al. [168].

To assess diversity in CONI, all sentences containing CED information are classified into a category and a sub-category based on the overall meaning of the sentence. If the coder is unable to determine a 
singular meaning for the sentence, then the sentence is classified based on the category of the first point made in the sentence. To score the diversity of a publication, categories that are reported are assigned a value of one, and categories that are not reported on are given a value of zero. These values are totalled to give the final score. The highest possible score for a document to receive is 18 .

The text is also coded on the quality of environmentally-relevant information disclosed in each sentence. This measurement is used to determine the "the level of information provided combined with the depth or detail of the disclosure" [168] (p. 213). This step includes examining each sentence containing environmental information and identifying, for each one, the "type" of disclosure based on whether the information present is high quality (Types 4 and 5), low quality (Types 1 and 2), or indeterminate (Type 3) (see Table 3 for examples). A Type 1 disclosure is the lowest quality disclosure; these are purely narrative disclosures (declarative statements) that tend to be vague, unclear, and present little material of value. Type 1 disclosures are commonly used when introducing topics or filling space. Type 2 disclosures are also narrative only or qualitative (i.e., as with Type 1, however, Type 2 disclosures offer significant information, including specific details and are generally more relevant than Type 1 disclosures). Disclosure Types 3, 4, and 5 all contain an aspect of quantitative disclosure. Numerical information must be measurements or data-relevant; for example, the inclusions of a year or counts of an insignificant element (e.g., the number of goals set for a year) do not meet the quantitative requirement of a Type 3, 4, or 5 disclosure. A Type 3 disclosure gives only or primarily quantitative information with little or no qualitative context. Type 4 disclosures include qualitative information along with a related narrative aspect or explanation. Type 5 disclosures have quantitative information that compares data for multiple years. Type 5 disclosures can have a narrative component, but it is not necessary. In general, identifying the quality of disclosure in a sentence is not difficult based on the specific requirements of each category.

Table 3. Examples of quality type disclosure classification.

\begin{tabular}{|c|c|c|}
\hline Disclosure Type & Example & Explanation \\
\hline Type 1 & $\begin{array}{l}\text { "Most importantly, we approach } \\
\text { sustainability as a long-term, } \\
\text { collaborative effort" [170] (p. 4) }\end{array}$ & $\begin{array}{l}\text { This sentence is vague and includes no } \\
\text { goal or plan for execution; because of } \\
\text { this, it offers little value. }\end{array}$ \\
\hline Type 2 & $\begin{array}{l}\text { "In November 2015, Monsanto signed } \\
\text { the White House American Business } \\
\text { Act on Climate Pledge, which affirmed } \\
\text { our commitment to climate action and } \\
\text { our support for a strong outcome from } \\
\text { the United Nations Framework } \\
\text { Convention on Climate Change } \\
\text { Conference in Paris (COP21) that took } \\
\text { place in December 2015" [171] (p. 53) }\end{array}$ & $\begin{array}{l}\text { This disclosure offers information } \\
\text { beyond a general level, including a } \\
\text { specific commitment and named } \\
\text { authority. Note the use of the year does } \\
\text { not count as quantitative information } \\
\text { and therefore does not make this } \\
\text { disclosure appropriate for Type } 4 \\
\text { classification. }\end{array}$ \\
\hline Type 3 & $\begin{array}{l}\text { “The Group's total energy consumption } \\
\text { meanwhile was even down } 2.8 \% \text { at } 80.8 \\
\text { petajoules" [172] (p. 132) }\end{array}$ & $\begin{array}{l}\text { This disclosure offers primarily } \\
\text { quantitative information with little } \\
\text { narration or explanation. }\end{array}$ \\
\hline Type 4 & $\begin{array}{l}\text { "Additionally, during the current year, } \\
\text { the Company has recognized the } \\
\text { business interruption claim amounting } \\
\text { to } 2500 \text { lakhs received from the } \\
\text { Insurance company on account of the } \\
\text { 'Hudhud' cyclone in Vishakapatnam } \\
\text { unit" [173] (p. 123) }\end{array}$ & $\begin{array}{l}\text { This sentence includes an element of } \\
\text { both quantitative and qualitative } \\
\text { information but does not provide a } \\
\text { comparison to other years. }\end{array}$ \\
\hline Type 5 & $\begin{array}{l}\text { [Chart format] “Total waste; Landfill; } \\
\text { FY14 8,600; FY15 7,060” [171] (p. 76) }\end{array}$ & $\begin{array}{l}\text { This chart entry contains comparative } \\
\text { data for the financial years } 2014 \text { and } \\
\text { 2015; a Type } 5 \text { disclosure does not } \\
\text { require a narrative component. }\end{array}$ \\
\hline
\end{tabular}




\subsection{Analysis}

The analysis was performed separately on the measures of quantity, diversity, and quality to preserve the multifaceted advantage of using the CONI method. The analysis focused on two main elements. First, a simple linear regression was used to indicate the significance of the change in a parameter over the time. Second, a repeated measures two-way ANOVA was used to assess the significance of the difference in reporting between corporation categories and the interaction over time. Using a repeated measures analysis helps to account for individual variability of a corporation and to identify corporations as having comparatively good or poor levels of disclosure.

\section{Results}

\subsection{Quantity}

The results for quantity scores are presented in Figures 1-4. In 2002, the mean quantity score for domestic corporations was 69.5, for I-MNCs was 50, and for P-MNCs was 230.25. By 2016, the mean quantities of CED material published were 233.5, 128.25, and 577 for domestic corporations, I-MNCs, and P-MNCs, respectively. Scores for the P-MNCs were much higher than those for the domestic and the I-MNCs. The scores of domestic corporations and I-MNCs were generally similar, although those for domestic firms had moved higher in recent years. The higher quantity, as reflected in the P-MNC's scores, was not surprising given their larger size and the greater complexity of their operations, particularly if they report on the CED activities throughout the enterprise. Beyond simply their greater size, due to their greater political visibility and the attention of regulators as well as their administrative and institutional capacity for reporting, large companies generally disclose more information $[87,115,174]$.

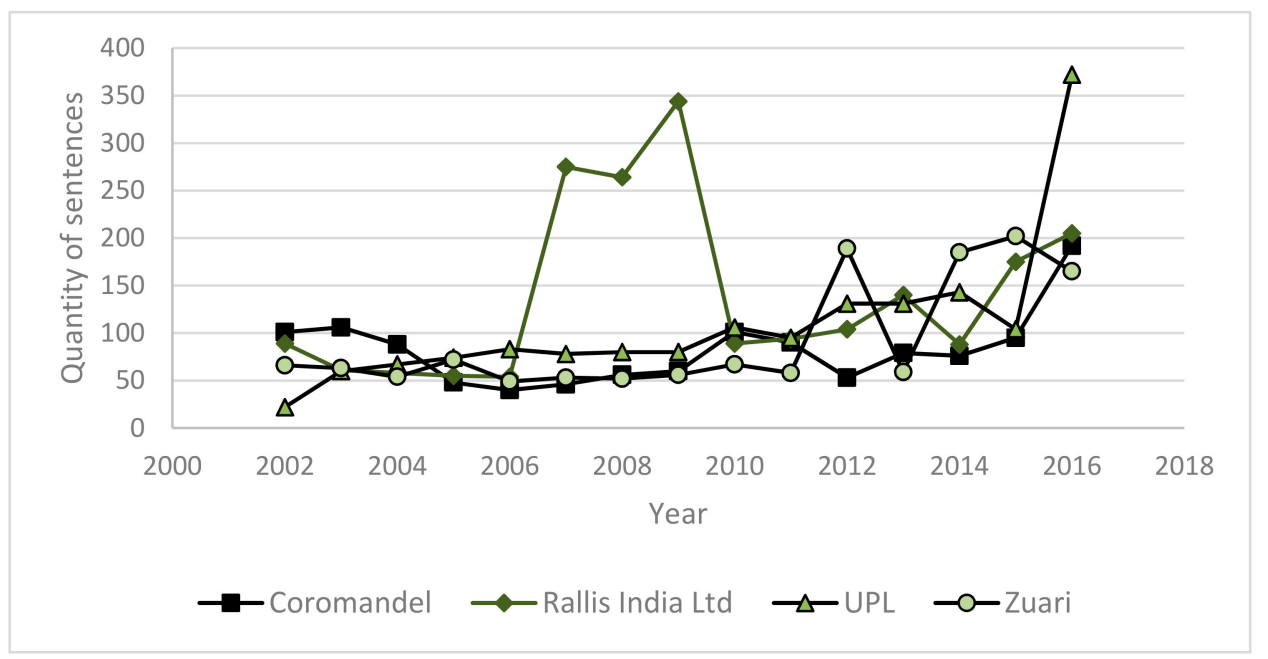

Figure 1. Total quantity of disclosures for domestic Indian corporations from 2002-2016. Coromandel $\left(p=2.126 \times 10^{-1}\right)$, Rallis India $(p=3.187 \times 10)$, United Phosphorus Ltd. (UPL) $\left(p=2.953 \times 10^{3}\right)$, Zuari $\left(p=3.492 \times 10^{3}\right)$. 


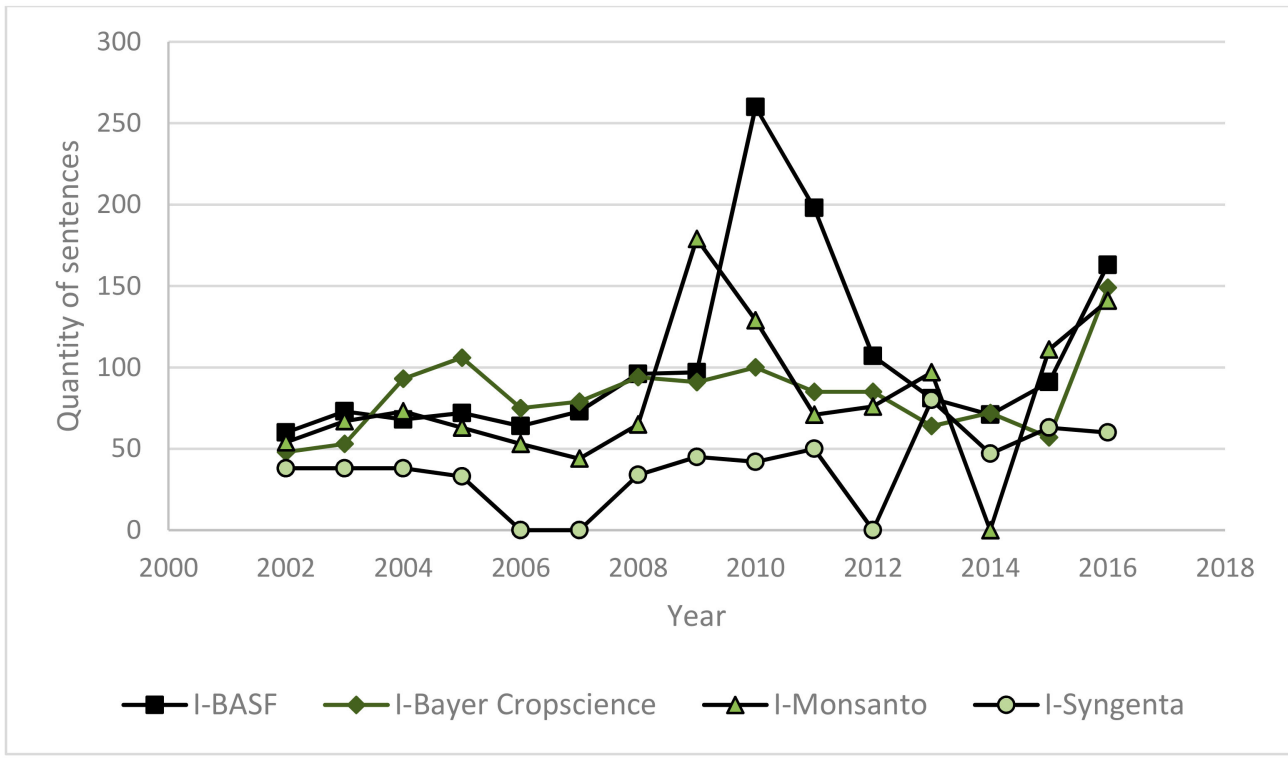

Figure 2. Total quantity of disclosure for Indian-based subsidiaries of the multinational corporation (I-MNCs) from 2002-2016. BASF India $(p=1.641 \times 10)$, Bayer India $(p=1.449 \times 10)$, Monsanto India $(p=2.742 \times 10)$, Syngenta India $\left(p=9.729 \times 10^{2}\right)$.

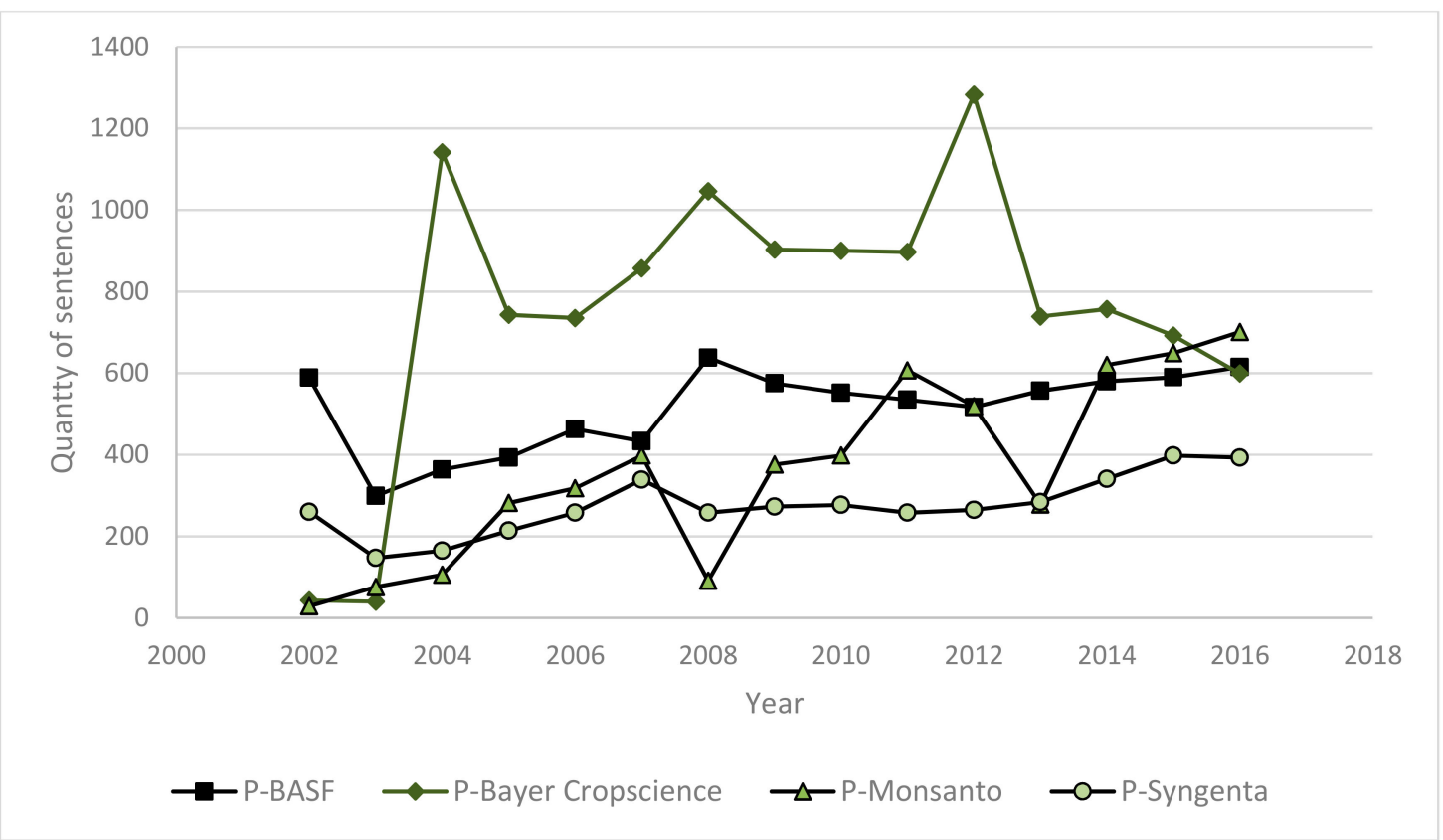

Figure 3. Total quantity of disclosure for parent multinational corporations (P-MNCs) from 2002-2016. $\operatorname{BASF}\left(p=1.236 \times 10^{2}\right)$, Bayer $(p=2.035 \times 10)$, Monsanto $\left(p=3.949 \times 10^{5}\right)$, Syngenta $\left(p=6.130 \times 10^{4}\right)$. 


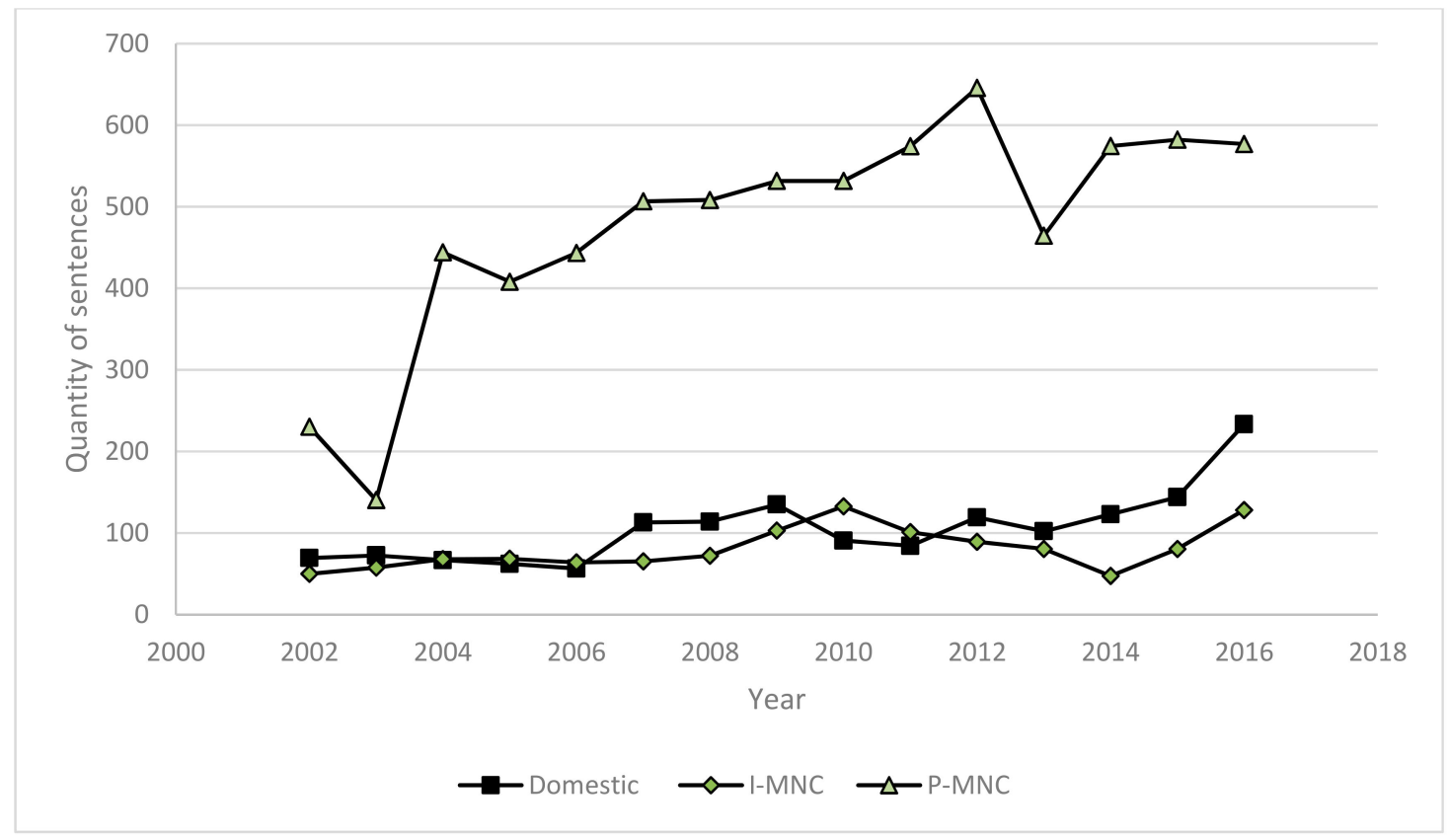

Figure 4. Mean quantity of disclosure for domestic Indian corporations, I-MNCs, and P-MNCs for 2002-2016. Domestic $\left(p=1.097 \times 10^{3}\right)$, I-MNC $\left(p=4.491 \times 10^{2}\right)$, P-MNC $\left(p=4.399 \times 10^{4}\right)$.

The change in quantity scores over time was statistically significant for two of the domestic corporations (UPL, $p=2.953 \times 10^{3}$; Zuari, $p=3.492 \times 10^{3}$ ) and three P-MNCs (BASF, $p=1.236 \times 10^{2}$; Monsanto, $p=3.949 \times 10^{5}$; Syngenta, $\left.p=6.130 \times 10^{4}\right)$. The quantity scores changed significantly over time for each category (domestic, $p=1.097 \times 10^{3}$; I-MNC, $p=4.491 \times 10^{2} ; \mathrm{P}-\mathrm{MNC}, p=4.399 \times 10^{4}$ ). Notably, the uptick in the quality scores for the I-MNCs and the domestic companies in recent years corresponded to the timing of the changes in the Companies Act in 2013.

Outliers in data included a cluster of reports from Rallis India for the years 2007, 2008, and 2009, UPL for the year 2016, BASF India for the year 2010, and Bayer CropScience for the years 2004 and 2012. Rallis India experienced an increase in profits following a period of losses in the years leading up to the publication of the highlighted reports; also, a new executive director came into office in 2007. UPL did not have outstanding financial growth leading up to 2016; however, the 2016 annual report, titled "Doing Things Better," highlighted the renewed importance of CSR performance. In 2010, BASF India faced a large merger between Ciba India Ltd. and BASF India, which increased company sales. No significant events connected to Bayer CropScience could be found around the year 2004; however, in 2012, a series of scientific articles $[175,176]$ and ensuing news articles reporting on the effects of neonicotinoid pesticides on bumblebees received significant attention. Bayer CropScience was particularly implicated, as they are leading producers of this class of pesticides. While these events cannot be exclusively used to explain the increase in the quantity of the reports published by these companies in specific years, it does suggest that corporations may vary their disclosure in response to external legitimacy challenges.

As indicated by previous research, P-MNCs did show a significantly higher quantity of CEDs $[13,120]$. Additionally, the rate of increase was higher for P-MNCs than for domestic corporations and I-MNCs (Figure 4). Despite that fact, that the quantity of disclosure increased over the fifteen years in each of the corporate categories, and an increasing gap could be seen between the quantity of disclosure from P-MNCs and the companies in the other categories.

\subsection{Diversity}

For each category of corporation, the diversity increased over time (Figures 5-8). In 2002, the mean diversity scores for domestic corporations, I-MNCs, and P-MNCs were 10, 9.25, and 11, respectively. 
By 2016, the mean diversity scores had increased to $13.5,14.25$, and 16.75 , respectively. The rate of increase in diversity for domestic and I-MNC corporations was similar, while the diversity scores increased more for P-MNCs-although most of that had already occurred by 2005 (Figure 8).

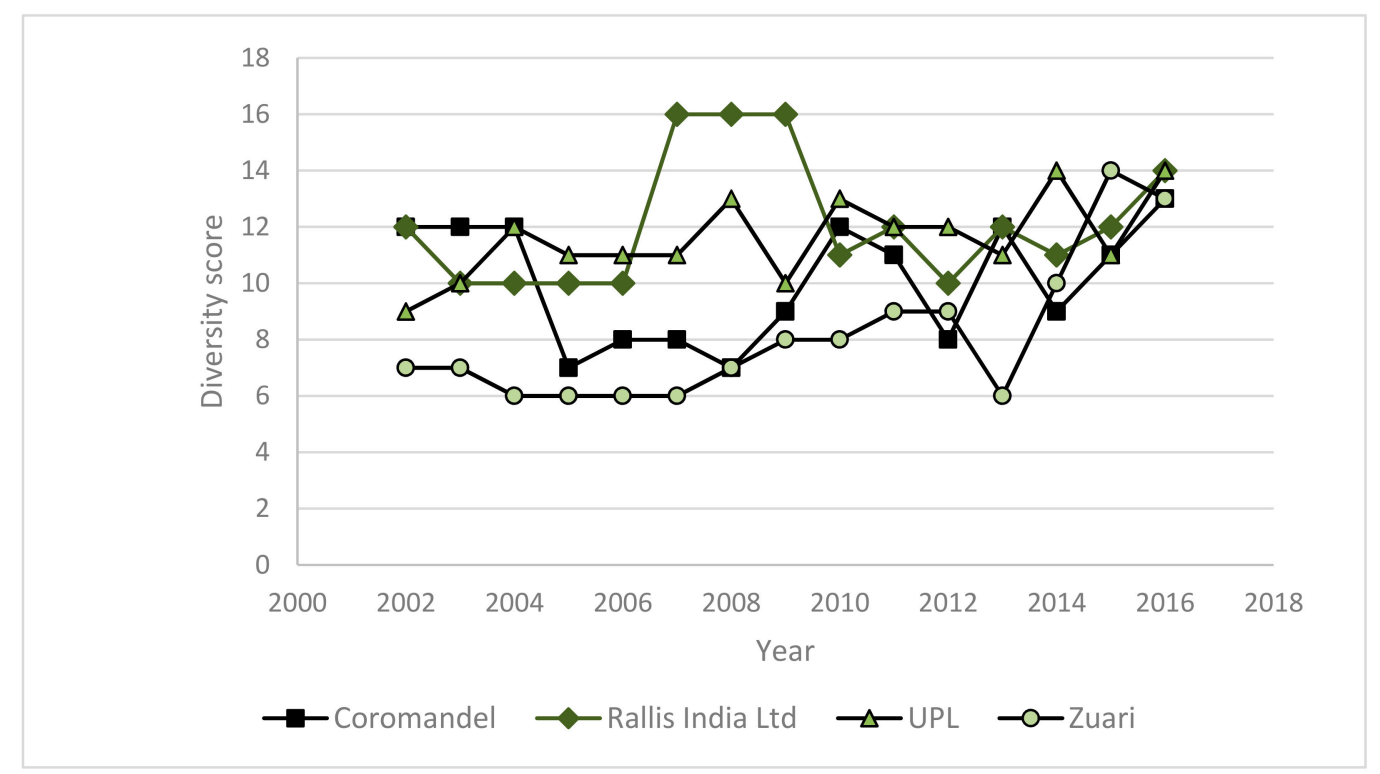

Figure 5. Total diversity score of disclosure for domestic Indian corporations from 2002-2016. Coromandel $(p=6.492 \times 10)$, Rallis India $(p=5.187 \times 10)$, UPL $\left(p=1.466 \times 10^{2}\right)$, Zuari $\left(p=1.083 \times 10^{3}\right)$.

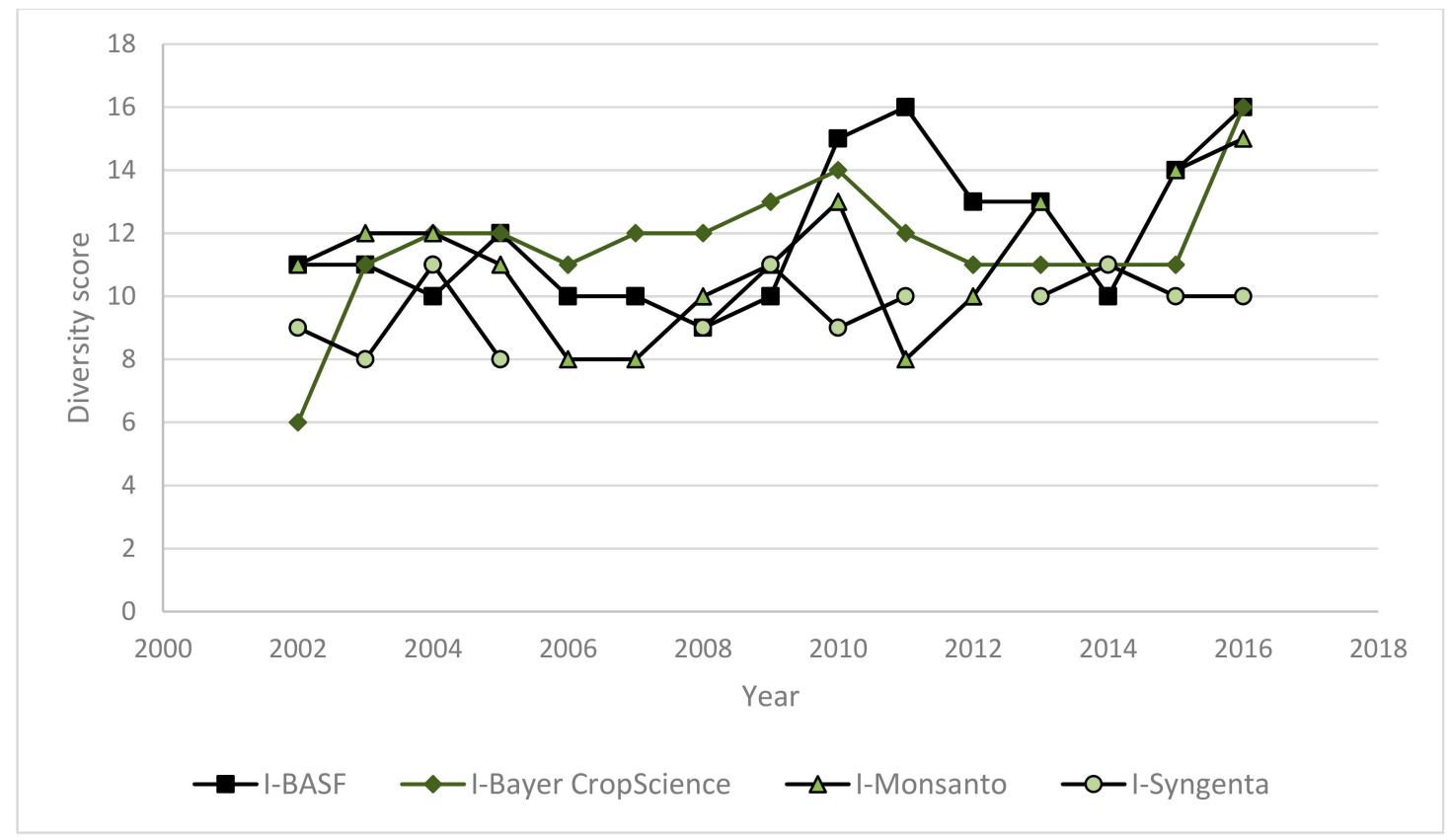

Figure 6. Total diversity score of disclosure for I-MNCs from 2002-2016. BASF India $\left(p=2.705 \times 10^{2}\right)$, Bayer India $\left(p=6.967 \times 10^{2}\right)$, Monsanto India $\left(p=1.615 \times 10^{3}\right)$, Syngenta India $(p=1.106 \times 10)$. 


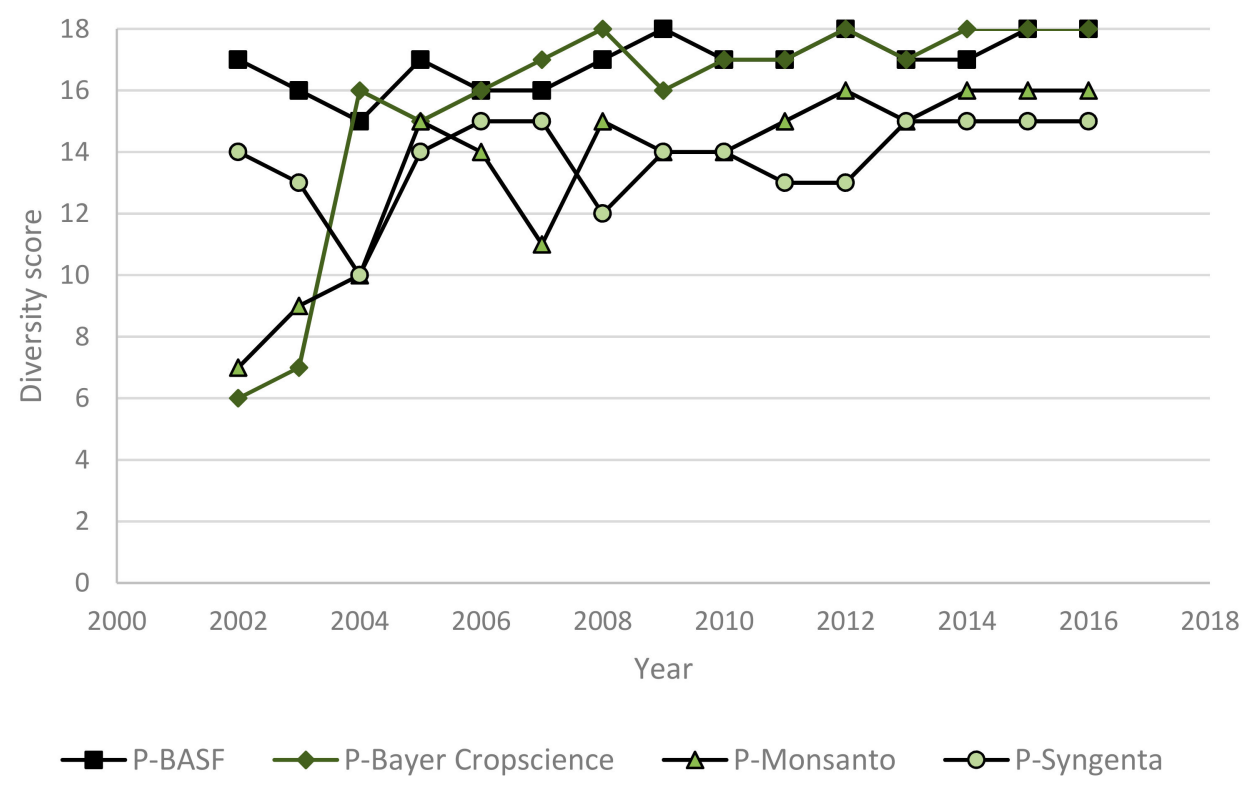

Figure 7. Total diversity score of disclosures for P-MNCs from 2002-2016. BASF $\left(p=6.416 \times 10^{3}\right)$, Bayer $\left(p=2.247 \times 10^{3}\right)$, Monsanto $\left(p=1.689 \times 10^{4}\right)$, Syngenta $\left(p=9.353 \times 10^{2}\right)$.

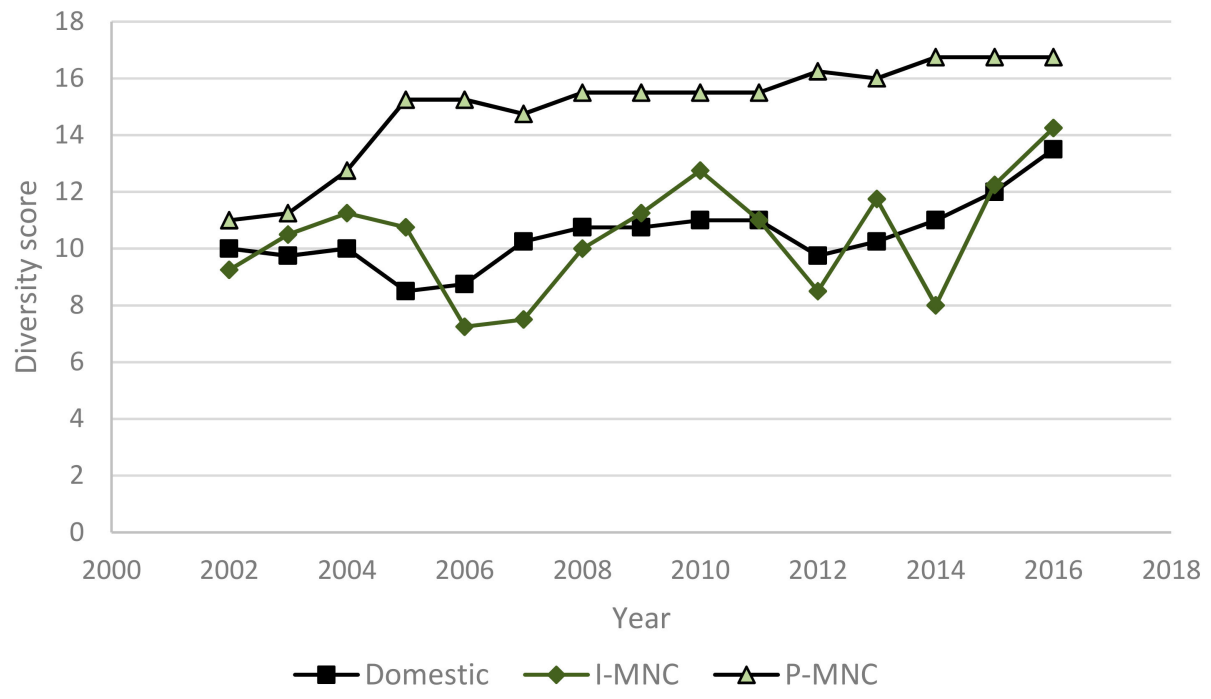

Figure 8. Mean diversity score of disclosures from domestic Indian corporations, I-MNCs, and P-MNCs from 2002-2016. Domestic $\left(p=2.728 \times 10^{3}\right), \mathrm{I}-\mathrm{MNC}(p=1.734 \times 10), \mathrm{P}-\mathrm{MNC}\left(p=2.667 \times 10^{5}\right)$.

The change in diversity over time was statistically significant for two of the domestic corporations (UPL, $p=1.466 \times 10^{2}$; Zuari, $p=1.083 \times 10^{3}$ ), one of the I-MNCs (BASF India, $p=2.705 \times 10^{2}$ ), and three P-MNCs (BASF, $p=6.416 \times 10^{3}$; Bayer, $p=2.247 \times 10^{3}$; Monsanto, $p=1.689 \times 10^{3}$ ). Overall, the change in diversity over time was statistically significant for domestic corporations $\left(p=2.728 \times 10^{3}\right)$ and P-MNCs $\left(p=2.667 \times 10^{5}\right)$ but not for I-MNCs $(p=1.734 \times 10)$.

Although the I-MNCs exhibited higher year-to-year variance in diversity than the domestic companies, overall, the two groups followed a similar trajectory. Most notable was that both achieved higher diversity scores since the changes to the Companies Act in 2013.

By 2016, two of the P-MNCs were reporting on all possible categories of disclosure, but the I-MNCs and the domestic corporations noticeably lacked disclosure in areas such as environmental 
responsibility/management (RES), pressure groups (PRESS), information retrieval process (IRP), responsible care (RC), and pollution (POLL). Some of these areas appear to be focal issues for companies operating in the agrochemical industry. As previously discussed, legitimacy is a key reason for disclosing information deemed desirable by societal pressures. I-MNCs and domestic corporations both operate in India, which means they both share some stakeholders (e.g., local community, customers, local government) that P-MNCs do not. In the absence of prescriptive direction through regulation, if I-MNCs and domestic corporations perceive a lack of interest in certain areas by the stakeholders in the societies in which they operate, they may choose not to disclose on these topics. Additionally, I-MNCs and domestic corporations may avoid disclosing information pertaining to these areas if they fear losing legitimacy based on poor or inadequate performance.

\subsection{Quality}

The quality of disclosures was determined by the type of disclosure (Type 1 to Type 5). Figures 9-11 summarize the nature of the disclosure as measured by the proportions of types for the domestic corporations, the I-MNCs, and the P-MNCs, respectively. Overall, declarative statements and qualitative disclosures (Types 1 and 2) were the most common; this in line with the literature [177]. Types 3 and 4 (that is, those that have quantitative content but do not provide comparison over time) were the least frequently presented. The proportions for Type 5 disclosures, which have quantitative information that compares data for multiple years, tended to fall between.

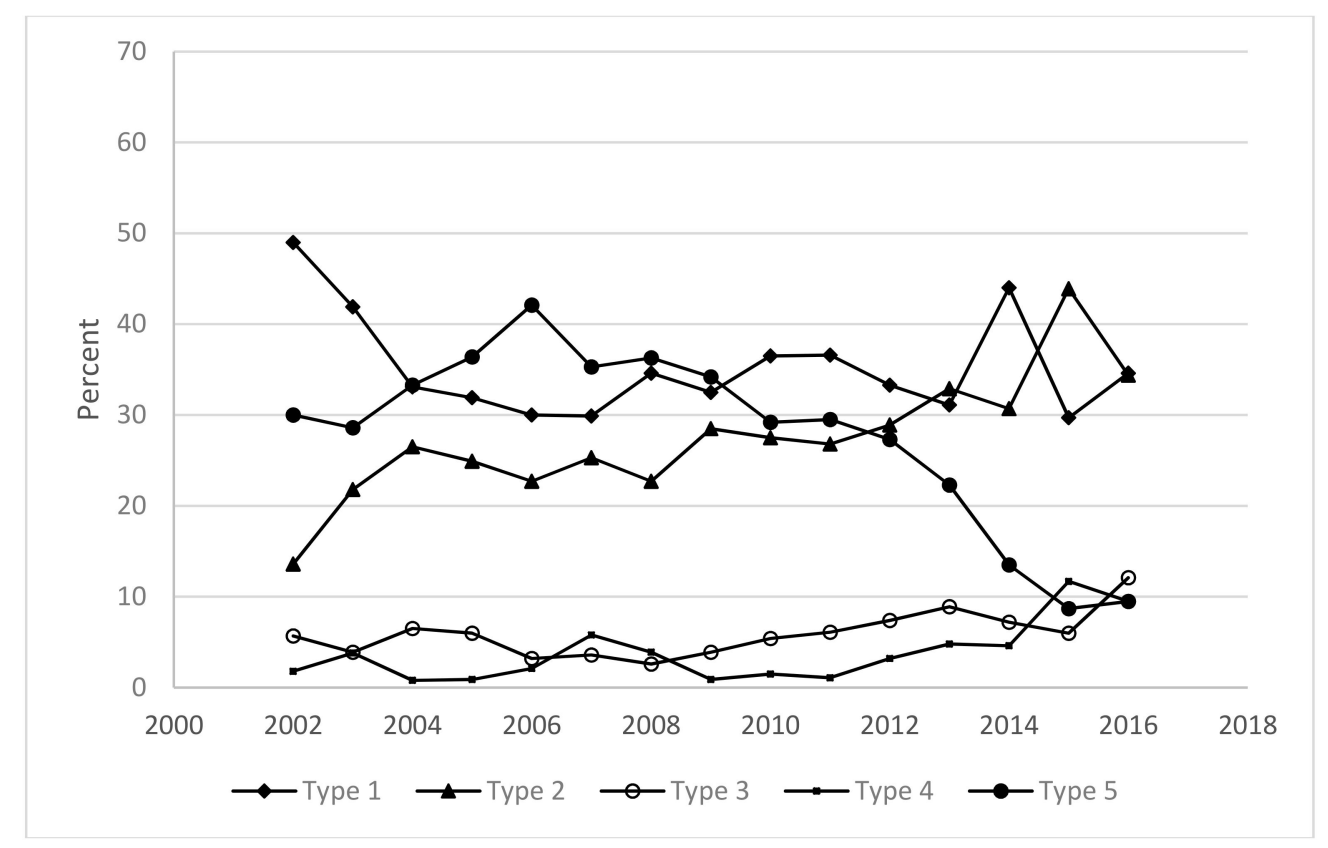

Figure 9. Quality composition of disclosures (as measured by percentage of total disclosure) by domestic companies from 2002-2016. 


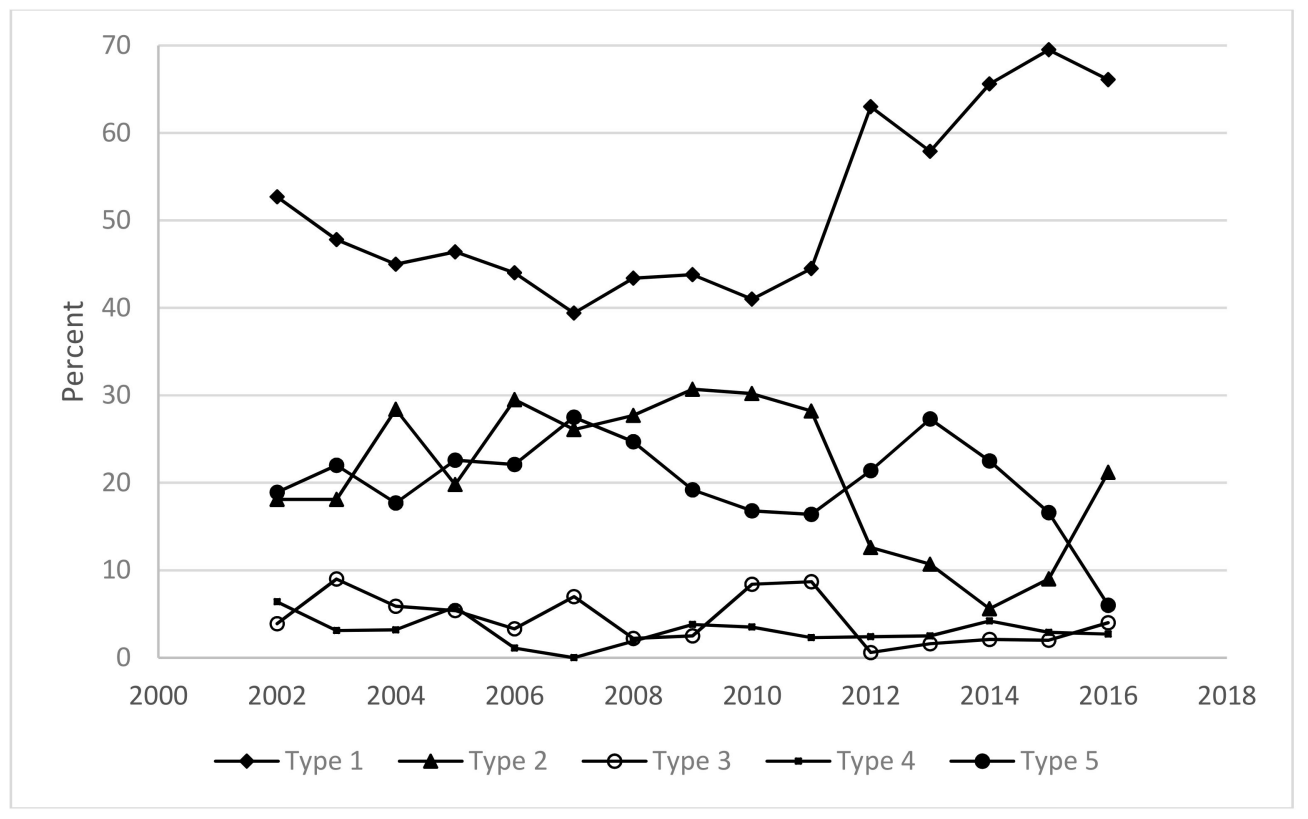

Figure 10. Quality composition of disclosures (as measured by percentage of total disclosure) by I-MNCs from 2002-2016.

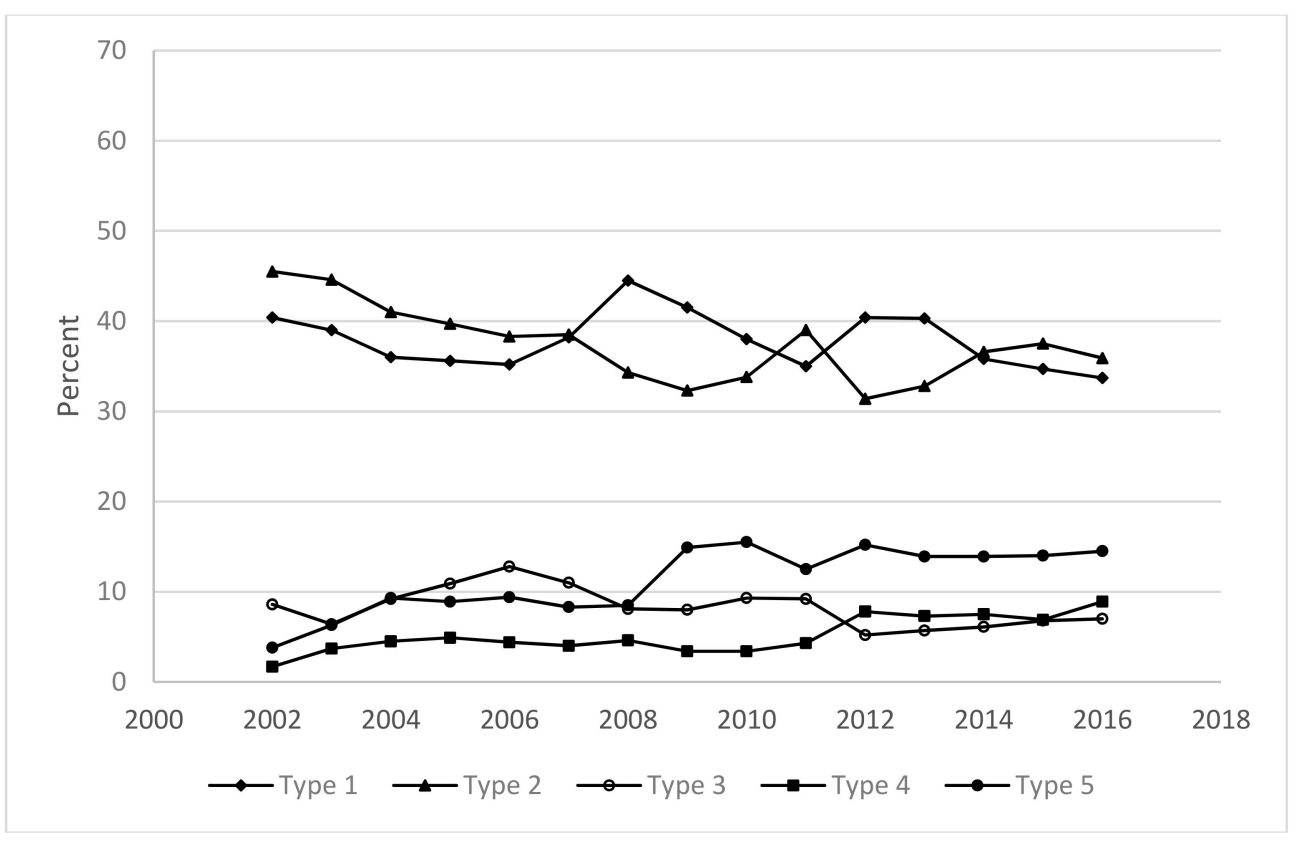

Figure 11. Quality composition of disclosures (as measured by percentage of total disclosure) by P-MNCs from 2002-2016.

Among domestic corporations, Types 1, 2, and 5 represented $80-90 \%$ of the disclosures. Type 1 remained consistently high throughout the study period. Type 2 disclosures became more important over time. Type 5 disclosures peaked in 2004-2007, largely as a result of changes in disclosures by one company (Rallis India); however, the proportion of Type 5 disclosures diminished thereafter with no indication of an effect of the changes to the Companies Act in 2013. However, the relatively small proportion of Type 4 disclosures did exhibit a notable uptick since those changes.

I-MNCs had higher proportions of Type 1 disclosures throughout the study period (representing $40-70 \%$ of disclosures). The proportions of Type 2 disclosures fell particularly after 2011, although their importance rebounded after 2014. Type 5 disclosures dropped after 2013. 
P-MNCs had the most consistent proportions of Type 1 and 2 disclosures over time but overall lower portions of high-quality disclosures (Type 4 and 5). However, the proportions of low-quality disclosures dropped over time as the proportions of Type 4 and 5 disclosures rose.

Deodhar [86] predicted that India's mandatory CSR reporting requirements might reduce the quality of related initiatives-although the introduction of mandatory environmental disclosure in China improved reporting quality [178]. There is some evidence in the changes in proportions of higher and lower level quantity disclosures that, for both domestic and I-MNC companies, high-quality disclosures (Type 4 and 5) declined after 2013 (Table 4) as the proportions of Types 1 and 2 disclosures increased.

Table 4. General trends of proportions of lower and higher quality disclosure over time from domestic corporations, I-MNCs, and P-MNCs.

\begin{tabular}{ccc}
\hline & Lower Quality Disclosures (Types 1 and 2) & Higher Quality Disclosures (Types 4 and 5) \\
\hline Domestic & $\uparrow$ & $\downarrow$ \\
\hline I-MNC & $\uparrow$ & $\downarrow$ \\
\hline P-MNC & $\downarrow$ & $\uparrow$ \\
\hline
\end{tabular}

The results indicate that P-MNCs exhibited the greatest increase in the quantity of disclosure. With this significant increase in the quantity of information published, P-MNC corporations also moved towards higher quality disclosures as lower quality narrative disclosures diminished proportionately. The more modest growth in the quantity and the diversity of disclosure among the domestic and the I-MNC companies was matched with generally declining quality as higher proportions of Types 1 and 2 disclosures replaced those of Types 4 and 5. Overall, in terms of the quality of disclosure, both Indian-based corporation categories more closely resembled each other and differed from the P-MNCs.

\subsection{Significance Testing: ANOVA}

In order to determine the degree of correspondence in CED among the three categories of companies, a repeated measures ANOVA analysis was performed to examine the relationship between publication year and the corporation category for diversity, quality, and quantity. Using a repeated measures analysis accounts for an individual corporation's change over time while analyzing the significance of the corporate category.

Results for the analysis of the quantity scores of disclosures showed that there was a statistically significant relationship for corporation category $\left(p>1.00 \times 10^{4}\right)$ and year $\left(p>1.00 \times 10^{4}\right)$ on CED quantity. Again, I-MNCs disclosed more similarly to local corporations rather than the parent corporations.

Results for the analysis of the diversity of disclosures showed statistical significance for both corporation category $\left(p>1.000 \times 10^{4}\right)$ and year $\left(p=7.00 \times 10^{4}\right)$. The category of corporations was significantly related to the diversity scores of the corporations' CEDs. The diversity of domestic corporations and I-MNCs were similar to one another, while P-MNC was much different. The disclosure among the I-MNCs more closely resembled that of domestic corporations than the parent corporations.

With respect to quality Types 1 and 2, both the corporation category and the year were statistically significant. For quality Type 3, neither the interaction nor the year were significant factors. However, the effect of the corporation category remained statistically significant. For quality Types 4 and 5, both the main effects and the interaction were significant, suggesting that, while the year and the corporation category had a significant effect on the portion of high-quality disclosures, this relationship may be changing over time. The results showed that there was a statistically significant difference between the quality of disclosures among the three categories of corporations. 


\section{Discussion}

Hypothesis 1 (H1). The corporations studied will increase the diversity, the quantity, and the quality of environmental disclosures over the whole time period examined.

Legitimacy theory provides insight as to why the diversity and the quantity of disclosures increased over time. Legitimacy theory is based on the proposition that corporations disclose to meet the expectations of society in order to maintain or obtain corporate legitimacy [53-55]. Public awareness of corporate environmental impacts has increased over the years $[179,180]$, in turn increasing the expectations of society for enhanced corporate responsibility [181]. In addition, there have been regulatory changes such as those associated with the Companies Act 2013, as well changes in external certification and codes and guidelines [182,183], which encourage improvement in CED. Overall, when society's expectations are higher, it is anticipated that corporations increase disclosure in order to maintain legitimacy.

The quantity of CED of each category of company increased, although P-MNC companies increased faster than the others and did so from a higher initial level in 2002. Similarly, while the corporations showed an overall general trend of increasing diversity, only in two of the categories (P-MNCs and domestic corporations) was the relationship statistically significant.

In terms of diversity, all categories began the timeframe with reasonably similar scores in 2002 (domestic: 10, I-MNC: 9.25, and P-MNC: 11). However, among the P-MNCs, the diversity of their CED increased more quickly than I-MNCs and domestic corporations. The increase in CEDs by P-MNCs was consistent with the expectations of the literature, which showed growing levels of reporting among large corporations $[14,184,185]$. Given the relatively high public visibility across multiple countries of P-MNCs, they could be more susceptible to public pressure to enhance reporting [14,185]. Additionally, although all corporations were exposed to increased societal expectations for CED, the P-MNCs may have had greater resources to respond [184-186]. I-MNCs and domestic corporations were similar in failing to report on diversity categories such as pressure groups, information retrieval process, and pollution. This suggests that there may be a lack of expectation for these types of disclosures. Unlike the situation with quantity scores, the domestic and the I-MNCs did not lag as far behind the P-MNCs in the change in diversity scores. To a certain extent, the differences appeared to represent a manifestation of the overall size of the P-MNC reports.

Raman [177] noted that, in India, qualitative disclosures had been by far the most frequent forms of reporting in CSR. That appears to have been the case in the companies under study. More recently, the results were more varied. There was a high degree of variability in the quality of CED reporting among the individual corporations and a lack of consistency between the categories of corporations. Corporations may respond to societal pressures by increasing the quantity of their reporting in order to obtain and maintain legitimacy, particularly in cases where they must be sensitive to stakeholder demands. This, however, does not necessarily mean that they increase the quality of their reporting. Corporations may attempt to secure legitimacy by increasing reporting quantity but failing to report on or accurately depict areas where they perform poorly.

Hypothesis 1a (H1a). In the period spanning the introduction and the implementation of the Companies Act 2013, the corporations studied will increase the diversity and the quantity environmental disclosures over the time period examined; however, change in the quality of disclosures will lag.

Statutory and regulatory requirements may be expected to drive convergence among firms operating in a given jurisdiction as they respond more to localized reporting practices. There is evidence to support that with respect to the changes in the quantity and the diversity of CED in the domestic and the subsidiary companies in the agrochemical industry. This follows the expectation of 
legitimacy theory. Overall, a notable uptick in both was observed. That noted, however, the P-MNC companies had significantly higher scores.

Hypothesis 2 (H2). The diversity, the quantity, and the quality of environmental disclosures of I-MNCs will be more similar to those of domestic corporations than those of the parent corporation.

The study also investigated the extent to which the reporting of CEDs of parent multinational corporations, their foreign subsidiaries in India, and domestic corporations resemble one another. Results from the two-way repeated measures ANOVA indicated that corporate category was a significant factor related to the diversity and the quantity of the CEDs. Further examination of the data revealed that domestic corporations and I-MNCs were most similar in their CED reporting practices, while the reporting practices of P-MNCs differed. Although the ANOVA analysis indicated that the quality scores were significantly related to the corporation category, it could not be determined conclusively that the I-MNCs were more similar to domestic corporations or P-MNCs in their reporting.

Previous research has found conflicting results on the influence of foreign ownership on CED. Results from this study suggest that foreign subsidiary companies operating in the same setting as domestic companies may respond similarly with respect to CED if they experience the same levels of external pressure on their legitimacy. However, they may also be expected to face issues of internal legitimacy by their parent corporations and their stakeholders. The results of examining the CED reporting among the companies found that I-MNCs reported more similarly to domestic corporations, suggesting the disclosure practices are localized. This aligns with Muller's observation that, "when a local context is a country with lower environmental standards, there is a risk that localization will lead subsidiaries to target those lower standards rather than the higher standards expected in their home country" [187] (p. 189). The result is, as Suddaby et al. [55] (p. 457) states, "complying with social pressures of legitimacy enhances the survivability of an organization and, as a result, creates a high degree of similarity among organizations in a common organizational field."

The results are consistent with I-MNCs wishing to reduce their "liability of foreignness" and therefore adapting to external legitimacy pressures $[57,58]$. They can do this by disclosing similar environmental information as domestic Indian companies. For example, high quantities of energy disclosures were observed for both subsidiaries and domestic Indian companies. The operational environment has a unique set of cultural, socio-economic, and political characteristics, and in order to survive (maintain legitimacy), companies must adapt to these unique pressures. As a result, companies that operate in the same institutional context tend to choose the same practices and strategies [62]. In other words, as Hillman and Wan [188] (p. 324) suggest, to maintain external legitimacy, "conformity among firm practices within countries is due to the overall pressure to conform to the institutional norms within the environment."

\section{Conclusions}

Although CSR in India has been favourably compared to that in other emerging economies $[189,190]$, many have noted a continuing lack of priority of CSR issues in India despite the moves to mandatory disclosure $[96,191]$. Indian CSR reports have often contained little related to environmental issues [37,177,192]. Even a recent study of the banking sector in India found the disclosure of sustainability considerations still in a "nascent" stage" [114] (p. 13). This research found that, over a fifteen-year period, each of the corporations from the agrochemical industry studied-subsidiary companies operating in India, their parent companies, and domestic Indian companies-had significant changes in the character of their CED. The results suggest that, in terms of diversity and quantity, subsidiary corporations generally conform more to localized reporting practices in India rather than resembling the parent companies' norms of CED.

The significance of this study of the agrochemical industry lies in several spaces: 
- This research adds to the body of literature that examines CED practices of companies in emerging economies and CED practices in India.

- It provides analysis of a time series examining trends in CED that support contentions that CSR in India has been improving over time.

- It adds to the research examining the effects of the Companies Act 2013 reforms on CED and puts that into the context of changes that had preceded them.

- The use of Consolidated Narrative Interrogation (CONI) allowed the differences in reporting between the subsidiary and the parent companies to be parsed out and offered some insight into the differences, despite the differences in the scale and the nature of the operations.

- Although some studies suggest that multinational corporations based in a developed economy with subsidiaries in developing countries result in more substantial disclosure by the subsidiaries than is the case with domestic companies [15-19], there is no sense that the multinational agrochemical corporations implemented comprehensive disclosure practices throughout the entirety of their operations or that reporting practices are more strongly associated with the practice of parent companies than those within country of operation. Rather, the reporting practices of subsidiary companies appear to reflect concerns of local legitimacy and parallel the nature of CED produced by domestic companies. This is particularly evident in the assessment of CED quality.

- As is the case with other research, this study illustrates the value of legitimacy theory as a construct for understanding CSR.

Improved CED can provide better insight into the operations, the environmental initiatives, and the auditing of corporations. Moreover, comprehensive disclosures have the potential to improve policy and auditing within a corporation-although there is no confirmed correlation with environmental performance $[56,65,161,193]$.

Limitations to this study include the concentration on a single industry that, despite its importance, may or may not be representative of industry more generally, and the fact that the research focused only on the situation in India, thereby limiting comparison with other jurisdictions. This research relied on a limited sample size due to the use of highly intensive and time-consuming manual coding. A limitation also arose from the fact that narratives of environmental information must be captured using a coding instrument, which is a difficult process. CONI had been used and tested for reliability in the past [168]. Since a coding manual was created for this research, this limitation was minimized, as evidenced by the results of inter- and intra-coder reliability testing. This research acknowledged it did not control for internal, firm-specific factors such as company size, leverage, profit, and corporate governance; therefore, the differences may, in part, reflect pressure from internal, firm-specific differences among the sample groups. Investigation of the relationship between environmental or financial performance and CED practice was beyond the scope of the study.

The principal focus of the study was on the operations in India. As a result, the comparison between the domestic and the subsidiary companies was the central concern, and the discussion concerning parent companies was more general, since the complications with introducing a review of the regulatory changes affecting the parent companies were not so much having to discuss the situations in an additional three countries but the fact that, as multinationals, the CED reporting generally (albeit inconsistently over time) can encompass their entire global operations. The result is that legal change in any of a number of countries may influence their CED.

Nonetheless, this study offers insights into the CED practices of multinational, subsidiary, and domestic corporations and provides a foundation for future research. Such research could include expanding the scope by considering subsidiaries of the same multinational corporation in different countries or within different industrial sectors. There would be merit in a comprehensive international review of existing studies to consolidate the understanding of the nature of the relationship between CED and subsidiary companies across multiple industries and countries. Although motivations for CED have been widely studied, there is less research specifically focused on understanding how 
stakeholder and institutional influences differ based on the location of operation and how this impacts the results of environmental disclosure by multinationals operating in multiple countries.

By using a longer time frame than has been used in previous research, the study extends the understanding of the evolution of CED practice in India in an important industry, and by incorporating the period before and after the changes introduced with the Companies Act 2013, the study adds to the relatively small number of CSR studies on the topic. Using the CONI method introduces quality measurements to the discussion of CED; thus, this research highlights the need for further research that considers evaluating more than the presence or the quantity of reporting on specific issues to include the consideration of the quality of CED.

Author Contributions: Conceptualization, A.J., N.W., M.B., and C.S.; Methodology, N.W.; Formal Analysis, A.J. and N.W.; Data Curation, A.J. and N.W.; Writing-Original Draft Preparation, A.J.; Writing-Review \& Editing, M.J., C.S. and N.W.; Supervision, M.J. and C.S.; Project Administration, M.J. and C.S.

Funding: This research was supported in part by the Natural Sciences and Engineering Research Council (NSERC) of Canada. The APC was funded by the Faculty of Engineering and Architectural Science at Ryerson University.

Conflicts of Interest: The authors declare no conflict of interest.

\section{References}

1. Wilmshurst, T.D.; Frost, G.R. Corporate environmental reporting: A test of legitimacy theory. Account. Audit. Account. 2000, 13, 10-26. [CrossRef]

2. Ingram, R.; Frazier, K. Environmental performance and corporate disclosure. J. Account. Res. 1980, 18, 614-622. [CrossRef]

3. Hu, Y.Y.; Karbharl, Y. Incentives and disincentives of corporate environmental disclosure: Evidence from listed companies in China and Malaysia. Thunderbird Int. Bus. Rev. 2015, 57, 143-161. [CrossRef]

4. Buhr, N.; Freedman, M. Culture, institutional factors and differences in environmental disclosure between Canada and the United States. Crit. Perspect. Account. 2001, 12, 293-322. [CrossRef]

5. Sumiani, Y.; Haslinda, Y.; Lehman, G. Environmental reporting in a developing country: A case study on status and implementation in Malaysia. J. Clean. Prod. 2007, 15, 895-901. [CrossRef]

6. Villiers, C.; van Staden, C.J. Where firms choose to disclose voluntary environmental information. J. Account. Public Policy 2011, 30, 504-525. [CrossRef]

7. Cormier, D.; Magnan, M. Corporate environmental disclosure strategies: Determinants, costs and benefits. J. Account. Audit. Financ. 1999, 14, 429-451. [CrossRef]

8. Cho, C.H.; Patten, D.M. The role of environmental disclosures as tools of legitimacy: A research note. Account. Organ. Soc. 2007, 32, 639-647. [CrossRef]

9. Stubbs, W.; Higgins, C.; Milne, M. Why do companies not produce sustainability reports? Bus. Strategy Environ. 2013, 22, 456-470. [CrossRef]

10. Mousa, G.A.; Hassan, N.T. Legitimacy theory and environmental practices: Short notes. Int. J. Bus. Stat. Anal. 2015, 2, 41-53. [CrossRef]

11. Hahn, R.; Lülfs, R. Legitimizing negative aspects in GRI-oriented sustainability reporting: A qualitative analysis of corporate disclosure strategies. J. Bus. Ethics 2014, 123, 401-420. [CrossRef]

12. Kolk, A.; Pinkse, J. The integration of corporate governance in corporate social responsibility disclosures. Corp. Soc. Responsib. Environ. Manag. 2010, 17, 15-26. [CrossRef]

13. KPMG. International Survey of Corporate Responsibility Reporting 2011; KPMG: Amsterdam, The Netherlands, 2011.

14. Ali, W.; Frynas, J.G.; Mahmood, Z. Determinants of corporate social responsibility (CSR) disclosure in developed and developing countries: A literature review. Corp. Soc. Responsib. Environ. Manag. 2017, 24, 273-294. [CrossRef]

15. Özen, S.; Küskü, F. Corporate environmental citizenship variation in developing countries: An institutional framework. J. Bus. Ethics 2009, 89, 297-313. [CrossRef]

16. Oh, W.; Change, Y.K.; Martynov, A. The effects of ownership structure on corporate social responsibility: Empirical evidence from Korea. J. Bus. Ethics 2011, 104, 283-297. [CrossRef] 
17. Khan, A.; Muttakin, M.B.; Siddiqui, J. Corporate governance and corporate social responsibility disclosures: Evidence from an emerging economy. J. Bus. Ethics 2013, 114, 207-223. [CrossRef]

18. Khlif, H.; Ahmed, K.; Souissi, M. Ownership structure and voluntary disclosure: A synthesis of empirical studies. Aust. J. Manag. 2017, 42, 376-403. [CrossRef]

19. Malarvizhi, P.; Yadav, S. Corporate environmental disclosures on the internet: An empirical analysis of Indian companies. Issues Soc. Environ. Account. 2008, 2, 211-232. [CrossRef]

20. Hossain, M.; Andrew, J. Corporate Social and Environmental Disclosure in Developing Countries: Evidence from Bangladesh; University of Wollongong Research: Wollongong, Australia, 2006; Available online: https://www.ssrn.com/abstract $\sim 2559110$ (accessed on 26 September 2018).

21. Da Silva Monteiro, S.M.; Aibar-Guzmán, B. Determinants of environmental disclosure in the annual reports of large companies operating in Portugal. Corp. Soc. Responsib. Environ. Manag. 2010, 17, 185-204. [CrossRef]

22. Zeng, S.X.; Xu, X.D.; Yin, H.T.; Tam, C.M. Factors that drive Chinese listed companies in voluntary disclosure of environmental information. J. Bus. Ethics 2012, 109, 309-321. [CrossRef]

23. Chaklader, B.; Gulati, P.A. A study of corporate environmental disclosure practices of companies doing business in India. Glob. Bus. Rev. 2015, 16, 321-335. [CrossRef]

24. Haladu, A.; Salim, B.B. Corporate ownership and sustainability reporting: Environmental agencies' moderating effects. Int. J. Econ. Financ. Issues 2016, 6, 1784-1790.

25. Elsayed, M.O.; Hoque, Z. Perceived international environmental factors and corporate voluntary disclosure practices: An empirical study. Br. Account. Rev. 2010, 42, 17-35. [CrossRef]

26. Khlif, H.; Hussainey, K.; Achek, I. The effect of national culture on the association between profitability and corporate social and environmental disclosure: A meta-analysis. Meditari Account. Res. 2015, 23, $296-321$. [CrossRef]

27. The World Bank. Indian Development Update: India's Growth Story; The World Bank: New Delhi, India, 2018; Available online: http://documents.worldbank.org/curated/en/814101517840592525/pdf/India-developmentupdate-Indias-growth-story.pdf (accessed on 31 July 2019).

28. International Monetary Fund (IMF). World Economic Outlook Update, July 2019: Still Sluggish Global Growth. 2019. Available online: https://www.imf.org/en/Publications/WEO/Issues/2019/07/18/WEOupdateJuly2019 (accessed on 31 July 2019).

29. Preuss, L.; Barkemeyer, R. CSR priorities of emerging economy firms: Is Russia a different shape of BRIC? Corp. Gov. 2011, 11, 371-385. [CrossRef]

30. Unsworth, J.B.; Shakil, N.A.; Kumar, G.A.; Kelter, G.A.; Linders, J.B.H.J. Agrochemicals. Chem. Int. 2012, 34, 34-36.

31. Sparks, T.; Lorbach, B. Perspective on the agrochemical industry and agrochemical discovery. Pest Manag. Sci. 2017, 73, 672-677. [CrossRef] [PubMed]

32. Research and Markets. Global Agrochemical Market: Trends Analysis \& Forecasts to 2021. 2016. Available online: https://www.researchandmarkets.com/research/jmv559/global (accessed on 3 October 2017).

33. Aktar, W.; Sengupta, D.; Chowdhury, A. Impacts of pesticides use in agriculture: Their benefits and hazards. Interdiscip. Toxicol. 2009, 2,1-12. [CrossRef]

34. Pray, C.E.; Nagarajan, L. The transformation of the Indian agricultural input industry: Has it increased agricultural R\&D? Agric. Econ. 2014, 45, 145-156.

35. Deegan, C.; Gordon, B. A study of environmental disclosure practices of Australian companies. Account. Bus. Res. 1996, 26, 187-199. [CrossRef]

36. Pahuja, S. Relationship between environmental disclosures and corporate characteristics: A study of large manufacturing companies in India. Soc. Responsib. J. 2009, 5, 227-244. [CrossRef]

37. Joshi, P.L.; Suwaidan, M.S.; Kumar, R. Determinants of environmental disclosures by Indian industrial listed companies: Empirical study. Int. J. Account. Financ. 2011, 3, 109-130. [CrossRef]

38. Hayes, T.B.; Hasen, M. From Silent Spring to silent night: Agrochemicals and the Anthropocene. Elem. Sci. Anthr. 2017, 5, 57. [CrossRef]

39. Quinteros, E.; Ribó, A.; Mejía, R.; López, A.; Belteton, W.; Comandari, A.; Orantes, C.M.; Pleites, E.B.; Hernández, C.E.; López, D.L. Heavy metals and pesticide exposure from agricultural activities and former agrochemical factory in a Salvadoran rural community. Environ. Sci. Pollut. Res. 2017, 24, 1662-1676. [CrossRef] [PubMed] 
40. Abraham, C.M.; Abraham, S. The Bhopal case and the development of environmental law in India. Int. Comp. Law Q. 1991, 40, 334-365. [CrossRef]

41. Sahay, A. Environmental reporting by Indian corporations. Corp. Soc. Responsib. Environ. Manag. 2004, 11, 12-22. [CrossRef]

42. O'Donovan, G. Environmental disclosures in the annual report: Extending the applicability and predictive power of legitimacy theory. Account. Audit. Account. 2002, 15, 344-371. [CrossRef]

43. Momin, M.A.; Parker, L.D. Motivations for corporate social responsibility reporting by MNC subsidiaries in an emerging country: The case of Bangladesh. Br. Account. Rev. 2013, 45, 215-228. [CrossRef]

44. Donaldson, T.; Preston, L.E. The stakeholder theory of the corporation: Concepts, evidence and implications. Acad. Manag. Rev. 1995, 20, 65-91. [CrossRef]

45. Fernando, S.; Laurence, S. A theoretical framework for CSR practices: Integrating legitimacy theory, stakeholder theory and institutional theory. J. Theor. Account. 2014, 10, 149-178.

46. Hörisch, J.R.; Freeman, E.; Schaltegger, S. Applying stakeholder theory in sustainability management. Organ. Environ. 2014, 27, 328-346. [CrossRef]

47. Mishra, S.; Suar, D. Do stakeholder management strategy and salience influence corporate social responsibility in Indian companies? Soc. Responsib. J. 2010, 6, 306-327. [CrossRef]

48. Lenssen, G.; Blagov, Y.; Bevan, D.; Arevalo, J.A.; Aravind, D. Corporate social responsibility practices in India: Approach, drivers, and barriers. Corp. Gov. 2011, 11, 399-414.

49. Campbell, D.; Craven, B.; Shrives, P. Voluntary social reporting in three FTSE sectors: A comment on perception and legitimacy. Account. Audit. Account. J. 2003, 16, 558-581. [CrossRef]

50. Arora, M.P.; Lodhia, S. The BP Gulf of Mexico oil spill: Exploring the link between social and environmental disclosure and reputation risk management. J. Clean. Prod. 2017, 140, 1287-1297. [CrossRef]

51. Deegan, C.; Rankin, M.; Tobin, J. An examination of the corporate social and environmental disclosures of BHP from 1983-1997: A test of legitimacy theory. Account. Audit. Account. J. 2002, 15, 312-343. [CrossRef]

52. Braam, G.; Weerd, L.; Hauck, M.; Huijbregts, M. Determinants of corporate environmental reporting: The importance of environmental performance and assurance. J. Clean. Prod. 2016, 129, 724-734. [CrossRef]

53. Dowling, J.; Pfeffer, J. Organizational legitimacy: Social values and organizational behavior. Pac. Sociol. Rev. 1975, 18, 122-136. [CrossRef]

54. Ashforth, B.E.; Gibbs, B.W. The double-edge of organizational legitimation. Organ. Sci. 1990, 1, 177-194. [CrossRef]

55. Suddaby, R.; Bitektine, A.; Haack, P. Legitimacy. Acad. Manag. Ann. 2017, 11, 451-478. [CrossRef]

56. Hughes, A.; Anderson, A.; Golden, S. Corporate environmental disclosures: Are they useful in determining environmental performance? J. Account. Public Policy 2001, 20, 217-240. [CrossRef]

57. Kostova, T.; Zaheer, S. Organizational legitimacy under conditions of complexity: The case of the multinational enterprise. Acad. Manag. Rev. 1999, 24, 64-81. [CrossRef]

58. Fiaschi, D.; Giuliani, E.; Nieri, F. BRIC Companies Seeking Legitimacy through Corporate Social Responsibility; Discussion Paper; University of Pisa: Pisa, Italy, 2014; Available online: https://www.ssrn.com/abstract = 2559110 (accessed on 26 September 2018).

59. Archel, P.; Husillos, J.; Larrinaga, C.; Spence, C. Social disclosure, legitimacy theory and the role of the state. Account. Audit. Account. 2009, 22, 1284-1307. [CrossRef]

60. Mahadeo, J.D.; Oogarah-Hanuman, V.; Soobaroyen, T. A longitudinal study of corporate social disclosures in a developing economy. J. Bus. Ethics 2011, 104, 545-558. [CrossRef]

61. Moneva, J.; Llena, F. Environmental disclosures in the annual reports of large companies in Spain. Eur. Account. Rev. 2000, 9, 7-29. [CrossRef]

62. DiMaggio, P.J.; Powell, W.W. The iron cage revisited: Institutional isomorphism and collective rationality in organizational fields. Am. Sociol. Rev. 1983, 48, 147-160. [CrossRef]

63. Kostova, T.; Roth, K. Adoption of an organizational practices by subsidiaries of multinational corporations: Institutional and relational effects. Acad. Manag. J. 2002, 45, 215-233.

64. Martínez-Ferrero, J.; García-Sánchez, I.M. Coercive, normative and mimetic isomorphism as determinants of the voluntary assurance of sustainability reports. Int. Bus. Rev. 2017, 26, 102-118. [CrossRef]

65. Christmann, P. Multinational companies and the natural environment: Determinants of global environmental policy standardization. Acad. Manag. J. 2004, 47, 747-760. [CrossRef] 
66. Orru, M. The institutional logic of small-firm economies in Italy and Taiwan. Stud. Comp. Int. Dev. 1991, 26, 3-28. [CrossRef]

67. Strang, D.; Meyer, J.W. Institutional conditions for diffusion. Theory Soc. 1993, 22, 487-511. [CrossRef]

68. Rosenzweig, P.M.; Singh, J.V. Organizational environments and the multinational enterprise. Acad. Manag. Rev. 1991, 16, 340-361. [CrossRef]

69. Pandey, S.C.; Pattnaik, P.N. Mandatory CSR and organizational compliance in India: The experience of Bharti Airtel. Glob. Bus. Organ. Excell. 2017, 36, 19-24. [CrossRef]

70. Gray, R.H.; Owen, D.; Adams, C. Accounting and Accountability: Changes and Challenges in Corporate Social and Environmental Reporting; Prentice Hall International: London, UK, 1996.

71. Hegde, P.; Bloom, R.; Fuglister, J. Social financial reporting in India: A case. Int. J. Account. 1997, 32, $155-172$. [CrossRef]

72. Kumar, R.; Murphy, D.F.; Balsari, V. Altered Images: The 2001 State of Corporate Responsibility in India Poll. Understanding and Encouraging Corporate Responsibility in South Asia, Update One; Tata Energy Research Institute: New Delhi, India, 2001.

73. Balasubramanian, N.K.; Kimber, D.; Siemensma, F. Emerging opportunities or traditions reinforced? An analysis of the attitudes towards CSR, and trends of thinking about CSR, in India. J. Corp. Citizensh. 2005, 17, 79-92. [CrossRef]

74. Sharma, A.K.; Talwar, B. Corporate social responsibility: Modern vis-à-vis Vedic approach. Meas. Bus. Excell. 2005, 9, 35-45. [CrossRef]

75. Narayan, A. Being a corporate citizen in India: History and situation today. Econ. Bus. J. 2014, 8, 1132-1139.

76. Cordeiro, J.J.; Galeazzo, A.; Shaw, T.S.; Veliyath, R.; Nandakumar, M.K. Ownership influences on corporate social responsibility in the Indian context. Asia Pac. J. Manag. 2018, 35, 1107-1136. [CrossRef]

77. Jamali, D.; Mirshak, R. Corporate social responsibility (CSR): Theory and practice in a developing country context. J. Bus. Ethics 2007, 72, 243-262. [CrossRef]

78. Subramaniam, N.; Kansal, M.; Babu, S. Governance of mandated corporate social responsibility: Evidence from Indian government-owned firms. J. Bus. Ethics 2017, 143, 543-563. [CrossRef]

79. Pramanik, A.K.; Shil, N.C.; Das, B. Corporate environmental reporting: An emerging issue in the corporate world. Int. J. Bus. Manag. 2008, 3, 146-154. [CrossRef]

80. Sen, M.; Mukherjee, K.; Pattanayak, J.K. Corporate environmental disclosure practices in India. J. Appl. Account. Res. 2011, 12, 139-156. [CrossRef]

81. Securities and Exchange Board of India. Business Responsibility Reports. 2012. Available online: https: //www.sebi.gov.in/legal/circulars/aug-2012/business-responsibility-reports_23245.html (accessed on 17 July 2019).

82. Narayanaswamy, R.; Raghunandan, K.; Rama, D.V. Corporate governance in Indian context. Account. Horiz. 2012, 26, 583-599. [CrossRef]

83. Abraham, S.; Marston, C.; Jones, E. Disclosure by Indian companies following corporate governance reform. J. Appl. Account. Res. 2015, 16, 114-137. [CrossRef]

84. Government of India, Ministry of Corporate Affairs. The Companies Act 2013. Available online: http: //www.mca.gov.in/Ministry/pdf/CompaniesAct2013.pdf (accessed on 24 April 2018).

85. Gatti, L.; Vishwanath, B.; Seele, P.; Cottier, B. Are We Moving beyond Voluntary CSR? Exploring Theoretical and Managerial Implications of Mandatory CSR Resulting from the New Indian Companies Act. J. Bus. Ethics 2018. Available online: https://doi.org/10.1007/s10551-018-3783-8 (accessed on 1 September 2019).

86. Deodhar, S.Y. Trapping India's CSR in a legal net: Will the mandatory trusteeship contribute to triple bottom line? J. Decis. Mak. 2016, 41, 267-274. [CrossRef]

87. Jain, R.; Winner, L.H. CSR and sustainability reporting practices of top companies in India. Corp. Commun. 2016, 21, 36-55. [CrossRef]

88. Goel, P.; Misra, R. Sustainability reporting in India: Exploring sectoral differences and linkages with financial performance. Vision 2017, 21, 214-224. [CrossRef]

89. Singh, S.; Holvoet, N.; Pandey, V. Bridging sustainability and corporate social responsibility: Culture of monitoring and evaluation of CSR initiatives in India. Sustainability 2018, 10, 2353. [CrossRef]

90. Mukherjee, A.; Bird, R. Analysis of mandatory CSR expenditure in India: A survey. Int. J. Corp. Gov. 2016, 7, 32-59. [CrossRef] 
91. Mukherjee, A.; Bird, R.; Duppati, G. Mandatory corporate social responsibility: The Indian experience. J. Contemp. Account. Econ. 2018, 14, 254-265. [CrossRef]

92. Fatima, A.H.; Abdullah, N.; Sulaiman, M. Environmental disclosure quality: Examining the impact of the stock exchange of Malaysia's listing requirements. Soc. Responsib. J. 2015, 11, 904-922. [CrossRef]

93. Ioannou, I.; Serafeim, G. The Consequences of Mandatory Corporate Sustainability Reporting. Harvard Business School Research Working Paper 11-100. 2017. Available online: https://pdfs.semanticscholar.org/ d849/80f213851ac1d2850e6beec278c083ab2976.pdf (accessed on 26 September 2018).

94. Tewari, R. Communicating corporate social responsibility in annual reports: A comparative study of Indian companies \& multi-national corporations. J. Manag. Public Policy 2011, 2, $22-51$.

95. Nurhayati, R.; Taylor, G.; Rusmin, R.; Tower, G.; Chatterjee, B. Factors determining social and environmental reporting by Indian textile and apparel firms: A test of legitimacy theory. Soc. Responsib. J. 2016, 12, 167-189. [CrossRef]

96. Goel, P. Rising standards of sustainability reporting in India: A study of impact of reforms in disclosure norms on corporate performance. J. Ind. Bus. Res. 2018. Available online: https://doi.org/10.1108/JIBR-06-2018-0166 (accessed on 1 September 2019). [CrossRef]

97. Chatterjee, B.; Mir, Z. The current status of environmental reporting by Indian companies. Manag. Audit. J. 2008, 23, 609-629. [CrossRef]

98. Mukherjee, K.; Sen, M.; Pattanaya, J.K. Firm characteristics and corporate environmental disclosure practices in India. IUP J. Account. Res. Audit. Pract. 2010, 9, 24-41.

99. Bhasin, N.; Kar, R.N.; Arora, N. Recent developments in environment disclosure practices of companies in India. In Proceedings of the 12th Asia Pacific Conference (APC 12) \& the 15th Asian Bioethics Conference (ABC 15), Kumamoto, Japan, 6-9 November 2014; pp. 395-401. Available online: http://r-cube.ritsumei.ac.jp/ repo/repository/rcube/6053/Proceedings-2\%20(as\%20of\%20Oct\%2029).pdf (accessed on 26 June 2019).

100. Debnath, S.; Bose, S.K.; Dhalla, R.S. Corporate environmental performance: An analysis of GRI compliant Indian organizations. Int. J. CSR Sustain. 2014, 1, 10-23.

101. Goyal, N. Corporate sustainability reporting practices among Indian companies-Myth or reality. Int. J. Manag. Soc. Sci. Res. 2014, 3, 54-60.

102. Maheshwari, M.; Kaura, P. Corporate social reporting and disclosure practice in India: An empirical investigation. Int. J. Res. 2014, 1, 1099-1109.

103. Kumar, V.; Gunasekaran, A.; Singh, K.; Papadopoulos, T.; Dubey, R. Cross sector comparison of sustainability reports of Indian companies: A stakeholder perspective. Sustain. Prod. Consum. 2015, 4, 62-71. [CrossRef]

104. Barman, J.K.; Gautam, H.C. Corporate environmental disclosure by Indian Companies-An empirical analysis. Int. J. Sci. Res. 2016, 5, 650-654.

105. Ezhilarasi, G.; Kabra, K.C. Corporate governance and environmental disclosure: Evidence from polluted companies in India. Res. Bull. 2016, 42, 38-49.

106. Malarvizhi, P.; Matta, R. 'Link between corporate environmental disclosure and firm performance'-perception or reality? Br. Account. Rev. 2016, 36, 107-117.

107. Omnamasivaya, B.; Prasad, M.S.V. The influence of financial performance on environmental accounting disclosure practices in India: Empirical evidence from BSE. IUP J. Account. Res. Audit. Pract. 2016, 15, 16-33.

108. Omnamasivaya, B.; Prasad, M.S.V. Factors influencing environmental accounting and disclosure practices in India: Empirical evidence from NIFTY companies. IUP J. Account. Res. Audit. Pract. 2016, 15, 21-34.

109. Omnamasivaya, B.; Prasad, M.S.V. Does financial performance really improve the environmental accounting disclosure practices in India: An empirical evidence from NIFTY companies. Afr. J. Econ. Sustain. Dev. 2017, 6, 52-66. [CrossRef]

110. Chandok, R.I.S.; Singh, S. Empirical study on determinants of environmental disclosure: Approach of selected conglomerates. Manag. Audit. J. 2017, 32, 332-355. [CrossRef]

111. Prasad, M.; Mishra, T.; Kalro, A.D. Environmental disclosure by Indian companies: An empirical study. Environ. Dev. Sustain. 2017, 19, 1999-2022. [CrossRef]

112. Murthy, V. Corporate social disclosure practices of top software firms in India. Glob. Bus. Rev. 2008, 9, 173-188. [CrossRef]

113. Joshi, M.; Sidhu, J.; Kansal, M. Corporate social disclosures in the knowledge-based sector in an emerging economy. Corp. Ownersh. Control 2013, 10, 237-249. [CrossRef] 
114. Kumar, K.; Prakash, A. Examination of sustainability reporting practices in Indian banking sector. Asian J. Sustain. Soc. Responsib. 2019, 4, 1-16. [CrossRef]

115. Gray, R.; Javad, M.; Power, D.M.; Sinclair, C.D. Social and environmental disclosure and corporate characteristics: A research note and extension. J. Bus. Financ. Account. 2001, 28, 327-356. [CrossRef]

116. Huafang, X.; Jianguo, Y. Ownership structure, board composition and corporate voluntary disclosure: Evidence from listed companies in China. Manag. Audit. J. 2007, 22, 604-619. [CrossRef]

117. Wang, M.-C. The relationship between firm characteristics and the disclosure of sustainability reporting. Sustainability 2017, 9, 624. [CrossRef]

118. Chappel, M.; Moon, J. Corporate social responsibility (CSR) in Asia: A seven country study of CSR. Bus. Soc. 2005, 44, 415-441. [CrossRef]

119. Sufian, M.A.; Zahan, M. Ownership structure and corporate social responsibility disclosure in Bangladesh. Int. J. Econ. Financ. Issues 2013, 3, 901-909.

120. Ezhilarasi, G.; Kabra, K.C. Factors influencing environmental disclosures: Evidence from India. IUP J. Account. Res. Audit. Pract. 2017, 16, 7-24.

121. Nurhayati, R.; Taylor, G.; Tower, G. Investigating social and environmental disclosure practices by listed Indian textile firms. J. Dev. Areas 2015, 49, 361-372. [CrossRef]

122. Narwal, M.; Singh, R. Corporate social responsibility practices in India: A comparative study of MNCs and Indian companies. Soc. Responsib. J. 2013, 9, 465-478. [CrossRef]

123. Park, B.I.; Ghauri, P.N. Determinants influencing CSR practices in small and medium sized MNE subsidiaries: A stakeholder perspective. J. World Bus. 2015, 50, 192-204. [CrossRef]

124. Gibson, K.; O’Donovan, G. Corporate governance and environmental reporting: An Australian study. Corp. Gov. 2007, 15, 944-956. [CrossRef]

125. Das Gupta, A. Social responsibility in India towards global compact approach. Int. J. Soc. Econ. 2007, 34, 637-663. [CrossRef]

126. Ragini. Corporate disclosure of intangibles: A comparative study of practices among Indian, US, and Japanese companies. Vikalpa 2012, 37, 51-72. [CrossRef]

127. Makori, D.M.; Jagongo, A. Environmental accounting and firm profitability: An empirical analysis of selected firms listed in Bombay Stock Exchange, India. Int. J. Hum. Soc. Sci. 2013, 3, 248-256.

128. Reid, E.M.; Toffel, M.W. Responding to public and private politics: Corporate disclosure of climate change strategies. Strateg. Manag. J. 2009, 30, 1157-1178. [CrossRef]

129. Luque-Vílchez, M.; Larrinaga, C. Reporting models do not translate well: Failing to regulate CSR reporting in Spain. Soc. Environ. Account. J. 2016, 36, 56-75. [CrossRef]

130. Liu, X.B.; Anbumozhi, V. Determinant factors of corporate environmental information disclosure: An empirical study of Chinese listed companies. J. Clean. Prod. 2009, 17, 593-600. [CrossRef]

131. Waagstein, P.R. The mandatory corporate social responsibility in Indonesia: Problems and implications. J. Bus. Ethics 2011, 98, 455-466. [CrossRef]

132. Ackers, B.; Eccles, N.S. Mandatory corporate social responsibility assurance practices: The case of King III in South Africa. Account. Audit. Account. J. 2015, 28, 515-550. [CrossRef]

133. O'Laughlin, B. Governing capital? Corporate social responsibility and the limits of regulation. Dev. Chang. 2008, 39, 945-957. [CrossRef]

134. Rodríguez, L.C.; LeMaster, J. Voluntary corporate social responsibility disclosure: SEC "CSR Seal of Approval". Bus. Soc. 2007, 46, 370-384. [CrossRef]

135. De Souza Gonçalves, R.; Weffort, E.F.J.; Peleias, I.R.; De Oliveira Goncalves, A. Social disclosure: Up to where should the regulation go? Int. J. Liabil. Sci. Enq. 2007, 1, 18-28.

136. Varottil, U. Analysing the CSR spending requirements under Indian company law. In Globalisation of Corporate Social Responsibility and Its Impact on Corporate Governance; Du Plessis, J.J., Varottil, U., Veldman, J., Eds.; Springer: Cham, Switzerland, 2018; pp. 231-253.

137. Bird, R.; Duppati, G.; Mukherjee, A. Corporate social responsibility and firm market performance: A study of Indian listed companies. Int. J. Bus. Gov. Ethics 2016, 11, 68-88. [CrossRef]

138. KPMG. India's CSR Reporting Survey 2015; KPMG: Amsterdam, The Netherlands, 2015.

139. Manchiraju, H.; Rajgopal, S. Does corporate social responsibility (CSR) create shareholder value? Evidence from the Indian Companies Act 2013. J. Account. Res. 2017, 55, 1257-1300. [CrossRef] 
140. KPMG. India's CSR Reporting Survey 2018; KPMG: Amsterdam, the Netherlands, 2018; Available online: https://assets.kpmg/content/dam/kpmg/in/pdf/2018/02/CSR-Survey-Report.pdf (accessed on 27 July 2019).

141. Dharmapala, D.; Khanna, V. The impact of mandated corporate social responsibility: Evidence from India's Companies Act of 2013. Int. Rev. Law Econ. 2018, 56, 92-104. [CrossRef]

142. Nair, A.K.; Bhattacharyya, S.S. Mandatory corporate social responsibility in India and its effect on corporate financial performance: Perspectives from institutional theory and resource-based view. Bus. Strategy Dev. 2019, 2, 106-116. [CrossRef]

143. Bergman, M.M.; Bergman, Z.; Teschemacher, Y.; Arora, B.; Jyoti, D.; Sengupta, R. Corporate responsibility in India: Academic perspectives on the Companies Act 2013. Preprints 2019, 2019080144. [CrossRef]

144. Bhatia, A.; Dhawan, A. Extent of corporate social responsibility reporting: India's transition from voluntary to mandatory regime. Int. J. Sustain. Strateg. Manag. 2018, 6, 73-99. [CrossRef]

145. Ghosh, S. Reporting of CSR activities in India: Are we still at a Nascent stage even after the legal mandate? In Corporate Social Responsibility in India: Cases and Development after the Legal Mandate; Nayan, M., René, S., Eds.; Springer: Cham, Switzerland, 2016; pp. 133-147.

146. Hahn, R.; Kühnen, M. Determinants of sustainability reporting: A review of results, trends, theory, and opportunities in an expanding field of research. J. Clean. Prod. 2013, 59, 5-21. [CrossRef]

147. Joshi, P.L.; Gao, S.S. Multinational corporations' corporate social and environmental disclosures (CSED) on web sites. Int. J. Commer. Manag. 2009, 19, 27-44. [CrossRef]

148. Gallo, P.J.; Christensen, L.J. Firm size matters: An empirical investigation of organizational size and ownership on sustainability-related behaviors. Bus. Soc. 2011, 50, 315-349. [CrossRef]

149. Cowen, S.S.; Ferreri, L.B.; Parker, L.D. The impact of corporate characteristics on social responsibility disclosure: A typology and frequency-based analysis. Account. Organ. Soc. 1987, 12, 111-122. [CrossRef]

150. Li, F. A survey of corporate social responsibility and corporate governance. In Research Handbook of Finance and Sustainability; Boubaker, S., Cumming, D., Nguyen, D.K., Eds.; Edward Elgar: Cheltenham, UK, 2018; pp. 126-138.

151. Cormier, D.; Gordon, I.M. An examination of social and environmental reporting strategies. Account. Audit. Account. J. 2001, 14, 587-617. [CrossRef]

152. Stanny, E.; Ely, K. Corporate environmental disclosures about the effects of climate change. Corp. Soc. Responsib. Environ. Manag. 2008, 15, 338-348. [CrossRef]

153. Choi, J. An investigation of initial voluntary environmental disclosures made in Korean semi-annual financial reports. Pac. Account. Rev. 1999, 11, 73-102.

154. Li, Y.; McConomy, B. An empirical examination of factors affecting the timing of environmental accounting standard adoption and the impact of corporate valuation. J. Account. Audit. Financ. 1999, 14, $279-313$. [CrossRef]

155. Neu, D.; Warsame, H.; Pedwell, K. Managing public impressions: Environmental disclosures in annual reports. Account. Organ. Soc. 1998, 23, 265-282. [CrossRef]

156. Sotorrío, L.L.; Sánchez, J.L.F. Corporate social reporting for different audiences: The case of multinational corporations in Spain. Corp. Soc. Responsib. Environ. Manag. 2010, 17, 272-283. [CrossRef]

157. Rahman, N.R.A.; Jauhari, H.H.M.; Roslan, N.F. An empirical examination of the relationship between environmental disclosure and financial performance in Malaysia. J. Contemp. Issues Thought 2013, 3, 77-92.

158. Momin, M. Corporate Social Responsibility and Reporting by Multinational Corporations in Bangladesh: An Exploration. Ph.D. Thesis, University of Glasgow, Glasgow, UK, 2006.

159. Luo, L.; Tang, Q.; Yi-Chen, L. Comparison of propensity for carbon disclosure between developing and developed countries. Account. Res. J. 2013, 26, 6-34. [CrossRef]

160. Adhikari, A.; Emerson, D.; Gouldman, A.; Tondkar, R. An examination of corporate social disclosure of multinational corporations: A cross-national investigation. Adv. Account. 2015, 31, 100-106. [CrossRef]

161. Hunter, T.; Bansal, P. How standard is standardized MNC global environmental communication? J. Bus. Ethics 2007, 71, 135-147. [CrossRef]

162. Darus, F.; Arshad, R.; Othman, S.; Jusoff, K. Influence of institutional pressure and ownership structure on corporate social responsibility disclosure. Interdiscip. J. Contemp. Res. Bus. 2009, 1, 123-150.

163. Riaz, Z.; Ray, S.; Ray, P.K.; Kumar, V. Disclosure practices of foreign and domestic firms in Australia. J. World Bus. 2015, 50, 781-792. [CrossRef] 
164. Datamonitor. Industry Profile: Fertilizer in North America. 2011. Available online: http://www.datamonitor. com/store/product/fertilizer_in_north_america?productid = 796669E2-3481-4D67-9682-72AB6AB45534 (accessed on 12 August 2011).

165. Clarkson, P.M.; Li, Y.; Richardson, G.D.; Vasvari, F.P. Revisiting the relation between environmental performance and environmental disclosure: An empirical analysis. Account. Organ. Soc. 2008, 33, 303-327. [CrossRef]

166. Holland, L.; Foo, Y.B. Differences in environmental reporting practices in the UK and the US: The legal and regulatory context. Br. Account. Rev. 2003, 35, 1-18. [CrossRef]

167. Krippendorff, K. Content Analysis: An Introduction to Its Methodology, 2nd ed.; Sage: Beverley Hills, CA, USA, 2004.

168. Beck, A.C.; Campbell, D.; Shrives, P.J. Content analysis in environmental reporting research: Enrichment and rehearsal of the methods in a British-German context. Br. Account. Rev. 2010, 42, 207-222. [CrossRef]

169. De Swert, K. Calculating Inter-coder Reliability in Media Content Analysis Using Krippendorff's Alpha; Center for Politics and Communication, Amsterdam University: Amsterdam, The Netherlands, 2012; Available online: http://www.polcomm.org/wp-content/uploads/ICR01022012.pdf (accessed on 30 April 2018).

170. Monsanto. Growing Better Together, 2016 Sustainability Report. 2017. Available online: https://monsanto. com/app/uploads/2017/05/2016-sustainability-report-2.pdf (accessed on 7 July 2019).

171. Monsanto. Growing Better Together, 2015 Sustainability Report. 2016; Available online: https://www. monsantoglobal.com/sustainability/documents/monsanto-2015-sustainability-report.pdf (accessed on 7 July 2019).

172. Bayer. Annual Report 2013. Available online: https://www.bayer.com/en/ar-2013.pdfx (accessed on 7 July 2019).

173. Coromandel. Annual Report 2015-16. Available online: https://coromandel.biz/downloads/AnnualReport_ 2015_16.pdf (accessed on 7 July 2019).

174. Brammer, S.; Pavelin, S. Factors influencing the quality of corporate environmental disclosure. Bus. Strategy Environ. 2008, 17, 120-136. [CrossRef]

175. Henry, M.; Beguin, M.; Requier, F.; Rollin, O.; Odoux, J.F.; Aupinel, P.; Aptel, J.; Tchamitchain, S.; Decourtye, A. A common pesticide decreases foraging success and survival in honey bees. Science 2012, 336, 348-350. [CrossRef]

176. Whitehorn, P.; O'Connor, S.; Wackers, F.; Goulson, D. Neonicotinoid pesticide reduces bumble bee colony growth and queen production. Science 2012, 336, 351-352. [CrossRef]

177. Raman, S.R. Corporate social reporting in India-A view from the top. Glob. Bus. Rev. 2006, 7, $313-324$. [CrossRef]

178. Wang, J.; Tian, G.; Fan, W.; Luo, D. The effects of mandatory regulation on corporate social responsibility reporting quality: Evidence from China. J. Appl. Bus. Res. 2017, 33, 67-86. [CrossRef]

179. Jain, S.K.; Kaur, G. Green marketing: An attitudinal and behavioural analysis of Indian consumers. Glob. Bus. Rev. 2004, 5, 187-205. [CrossRef]

180. Khan, A.; Khan, M.N.; Siddiqui, T.Z. Gauging attitudes towards the environment through NEP: A case study from India. Int. J. Soc. Entrepreneurship Innov. 2013, 2, 42-51. [CrossRef]

181. Alrazi, B.; de Villiers, C.; van Staden, C.J. A comprehensive literature review on, and the construction of a framework for, environmental legitimacy, accountability and proactivity. J. Clean. Prod. 2015, 102, 44-57. [CrossRef]

182. Gautam, R.; Singh, A. Corporate social responsibility practices in India: A study of top 500 companies. Glob. Bus. Manag. Res. 2010, 2, 41-56.

183. Aggarwal, P.; Singh, A.K. CSR and sustainability reporting practices in India: An in-depth content analysis of top-listed companies. Soc. Responsib. J. 2018. Available online: https://doi.org/10.1108/SRJ-03-2018-0078 (accessed on 1 September 2019). [CrossRef]

184. Lu, Y.; Abeysekera, I. Stakeholders' power, corporate characteristics, and social and environmental disclosure: Evidence from China. J. Clean. Prod. 2014, 64, 426-436. [CrossRef]

185. Ortas, E.; Gallego-Alvarez, I.; Etxeberria, I.A. Financial factors influencing the quality of corporate social responsibility and environmental management disclosure: A quantile regression approach. Corp. Soc. Responsib. Environ. Manag. 2014, 22, 362-380. [CrossRef] 
186. Qiu, Y.; Shaukat, A.; Tharyan, R. Environmental and social disclosures: Link with corporate financial performance. Br. Account. Rev. 2016, 48, 102-116. [CrossRef]

187. Muller, A. Global versus local CSR strategies. Eur. Manag. J. 2006, 24, 189-198. [CrossRef]

188. Hillman, A.J.; Wan, W.P. The determinants of MNE subsidiaries' political strategies: Evidence of institutional duality. J. Int. Bus. Stud. 2005, 36, 322-340. [CrossRef]

189. Alon, I.; Lattemann, C.; Fetscherin, M.; Li, S.; Schneider, A.M. Usage of public corporate communications of social responsibility in Brazil, Russia, India and China (BRIC). Int. J. Emerg. Mark. 2010, 5, 6-22. [CrossRef]

190. Bhatia, A.; Tuli, S. An empirical analysis of sustainability disclosure practices: Evidence from India and China. IIM Kozhikode Soc. Manag. Rev. 2014, 3, 135-148. [CrossRef]

191. Kumar, K.S.V.; Devi, V.R. Sustainability reporting practices in India: Challenges and prospects. In Proceedings of the Twelfth AIMS International Conference on Management, Kozhikode, India, 2-5 January 2015; Indian Institute of Management: Kozhikode, India, 2015. Available online: http:/www.aims-international.org/ aims12/12A-CD/PDF/K465-final.pdf (accessed on 17 June 2019).

192. Das, D.; Pramanik, A. Nature of social disclosure in corporate annual reports: A study of manufacturing companies listed in Indian Stock Exchange. Sch. J. Econ. Bus. Manag. 2015, 2, 1008-1016.

193. Meng, X.; Zeng, S.; Shi, J.J.; Qi, G.Y.; Zhang, Z.B. The relationship between corporate environmental performance and environmental disclosure: An empirical study in China. J. Environ. Manag. 2014, 145, 357-367. [CrossRef] [PubMed]

(C) 2019 by the authors. Licensee MDPI, Basel, Switzerland. This article is an open access article distributed under the terms and conditions of the Creative Commons Attribution (CC BY) license (http://creativecommons.org/licenses/by/4.0/). 